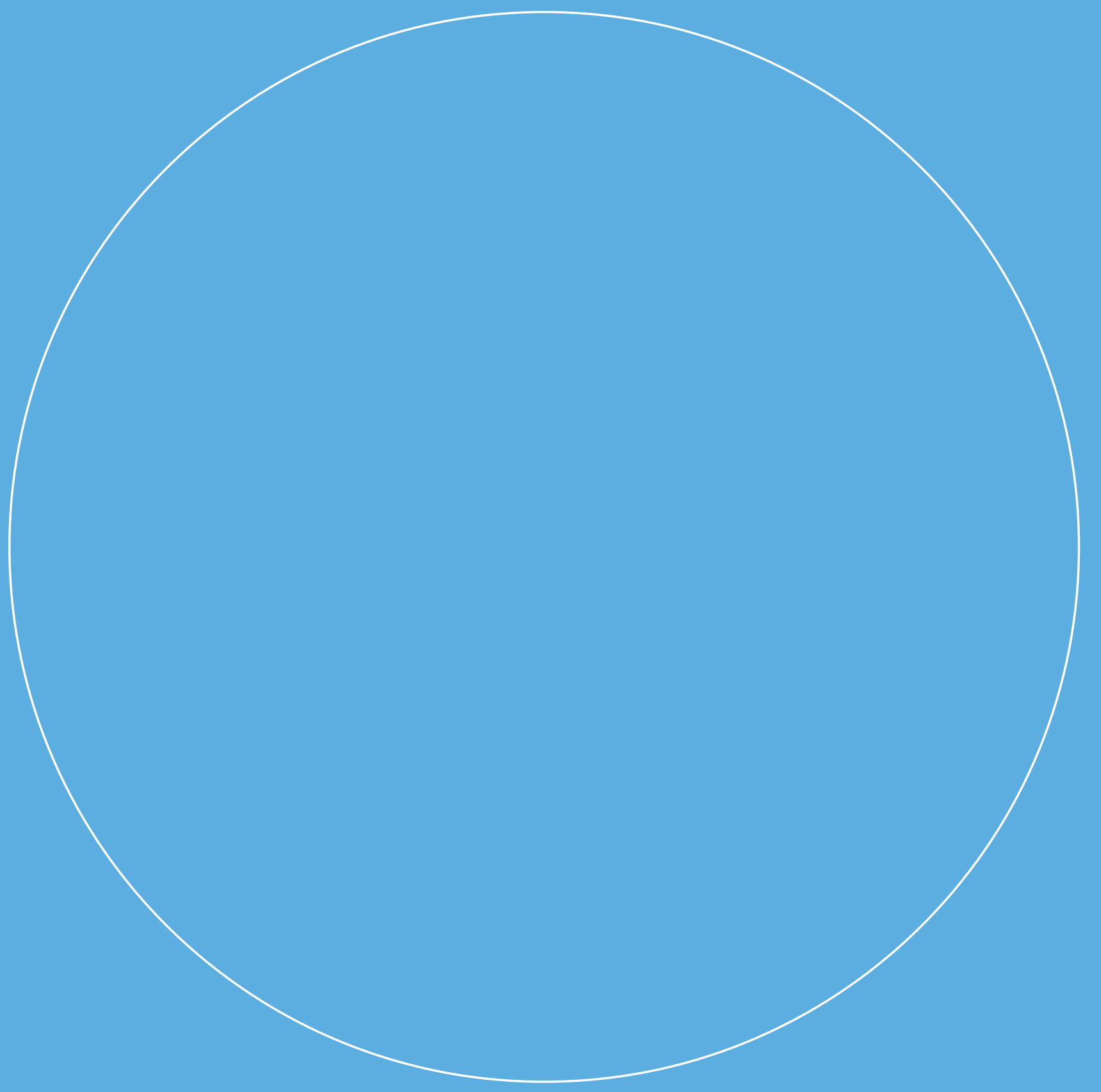

\title{
Review and analysis of studies on sustainability of cultured meat
}

Iris Vural Gursel, Mark Sturme, Jeroen Hugenholtz, Marieke Bruins 



\section{Review and analysis of studies on sustainability of cultured meat}

Authors: $\quad$ Iris Vural Gursel, Mark Sturme, Jeroen Hugenholtz, Marieke Bruins

This study was carried out by Wageningen Food \& Biobased Research, subsidised and commissioned by the Dutch Ministry of Agriculture, Nature and Food Quality.

Wageningen Food \& Biobased Research

Wageningen, January 2022 
WFBR Project number: 6224117000

Version: Final

Reviewed by: Lesly Garcia Chavez, Stacy Pyett

Approved by: Jan Jetten

Subsidized by: the Dutch Ministry of Agriculture, Nature and Food Quality

Commissioned by: the Dutch Ministry of Agriculture, Nature and Food Quality

Confidentiality of the report: Public

The research that is documented in this report was conducted in an objective way by researchers who act impartial with respect to the client(s) and sponsor(s). This report can be downloaded for free at https://doi.org/10.18174/563404 or at www.wur.eu/wfbr (under publications).

(C) 2022 Wageningen Food \& Biobased Research, institute within the legal entity Stichting Wageningen Research.

The client is entitled to disclose this report in full and make it available to third parties for review. Without prior written consent from Wageningen Food \& Biobased Research, it is not permitted to:

a. partially publish this report created by Wageningen Food \& Biobased Research or partially disclose it in any other way;

b. use this report for the purposes of making claims, conducting legal procedures, for (negative) publicity, and for recruitment in a more general sense;

c. use the name of Wageningen Food \& Biobased Research in a different sense than as the author of this report.

PO box 17, 6700 AA Wageningen, The Netherlands, T + 31 (0)317 4800 84, E info.wfbr@wur.nl, www.wur.eu/wfbr.

All rights reserved. No part of this publication may be reproduced, stored in a retrieval system of any nature, or transmitted, in any form or by any means, electronic, mechanical, photocopying, recording or otherwise, without the prior permission of the publisher. The publisher does not accept any liability for inaccuracies in this report. 


\section{Contents}

Preface

Summary

FAQs

1 Introduction

2 Process, scale and costs of cultured meat production

2.1 Cultivation process

2.2 Limitations in cultured meat production 11

2.2.1 Cell types 12

2.2.2 Medium requirements for cultured meat $\quad 12$

2.2.3 Energy requirements of cultured meat 13

2.3 Summarizing technical bottlenecks 13

$\begin{array}{ll}2.4 & \text { Other processed meat replacers } \\ & 13\end{array}$

$\begin{array}{lll}2.4 .1 & \text { Plant-based burgers } & 13\end{array}$

$\begin{array}{ll}2.4 .2 \text { Quorn } & 13\end{array}$

$\begin{array}{ll}2.4 .3 \text { Microbial biomass } & 14\end{array}$

$3 \quad$ Sustainability of cultured meat $\quad 15$

3.1 LCA methodology 15

3.2 LCA studies on cultured meat production 15

$\begin{array}{lll}\text { 3.3 Review of the goal and scope of reviewed studies } & 16\end{array}$

$\begin{array}{lll}3.3 .1 \text { Goal } & 16\end{array}$

3.3.2 Functional unit 16

$\begin{array}{ll}\text { 3.3.3 Temporal, geographical and technological coverage } & 16\end{array}$

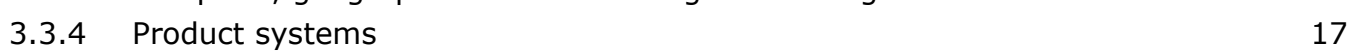

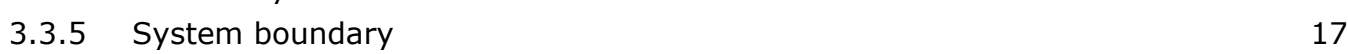

$\begin{array}{ll}\text { 3.3.6 Method for handling multifunctionality } & 19\end{array}$

$\begin{array}{ll}\text { 3.3.7 Impact assessment method and impact categories } & 19\end{array}$

$\begin{array}{lll}3.4 & \text { Review of inventory data used in reviewed studies } & 21\end{array}$

$\begin{array}{ll}3.5 & \text { Review of impact assessment results } \\ & 21\end{array}$

$\begin{array}{ll}\text { 3.5.1 Global Warming Potential } & 21\end{array}$

3.5.2 Energy use (Cumulative Energy Demand) 22

3.5.3 Land use 23

$\begin{array}{lll}3.5 .4 & \text { Water use } & 23\end{array}$

3.5.5 Other impact categories 23

3.6 Comparison with meat and other meat alternatives 24

3.7 Interpretation: hotspots and sensitivity analysis 26

3.8 Discussion on methodological choices and recommendations 28

3.8.1 System boundaries $\quad 28$

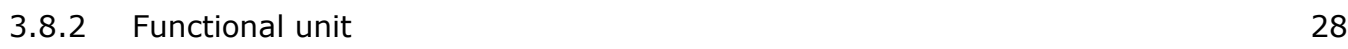

$\begin{array}{ll}\text { 3.8.3 Impact categories and assessment methods } & 29\end{array}$

3.8.4 Allocation method $\quad 29$

3.9 Sustainability issues beyond LCA 29

$\begin{array}{lll}3.9 .1 & \text { Health } & 29\end{array}$

$\begin{array}{lll}3.9 .2 & \text { Animal welfare } & 30\end{array}$

$\begin{array}{ll}3.9 .3 \text { Sensory properties } & 30\end{array}$

$\begin{array}{lll}3.9 .4 & \text { Trade-offs } & 30\end{array}$

3.10 Overall conclusions 31 
$5 \quad$ References

$6 \quad$ Appendix

38

Appendix 1 - Cultured meat medium components

38

Appendix 2 - Key assumptions of LCA-studies

41 


\section{Preface}

Cultured meat is currently advertised, publicly and commercially, as the sustainable, animal-friendly and cost-effective alternative to "real" meat produced by various livestock sources such as beef, swine, poultry and marine animals. However, the available scientific literature on this topic is scarce, difficult to interpret, and sometimes confusing. For this reason it is very difficult or even impossible for the Dutch Ministry of Agriculture, Nature and Food Quality (LNV) to determine a clear position on cultured meat with respect to policy-making and support for a protein transition in the AgriFood sector within the Netherlands. LNV has asked Wageningen University \& Research to provide an independent evaluation of the cultured meat technology with respect to sustainability and technical and economic feasibility in comparison with other meat/protein alternatives. 


\section{Summary}

Protein alternatives are crucial for a sustainable food production in future. Cultured meat is presented as a good alternative for consumers who want to be more sustainable but do not wish to change their diet. To validate this sustainability claim, this report evaluates four LCA studies on cultured meat. When comparing overall environmental impact of cultured meat with conventional meat products and other meat substitutes, cultured meat was seen to perform significantly better than beef, favourable to pork, similar to chicken, and worse than plant-based alternatives considering current global average production impacts.

It is important to realize that currently no commercial-scale cultured meat facility is operational. All LCA studies modelled a future facility, extrapolating scientific and small-scale facilities. Differences in system boundaries lead to high variability of environmental impact results for cultured meat among reviewed studies. The LCA system boundaries mostly include the cultivation-related processes, while product formulation and distribution are not taken into account. An important technical bottleneck that is not addressed are the large volumes of the fermenters and the extended cultivation times, which will need extraordinary sterility measures.

The LCA overview shows that cultured meat production is energy intensive and that energy consumption have the highest contribution in the overall impact. Next, growth medium production showed significant contribution to impact, especially the amino acid production and recombinant protein production for growth factors. Sensitivity analysis of model parameters showed that parameter choices on cell density and medium use impacted the results most.

Technically, the cultured meat industry is still very much in development. Obvious improvements that are needed are the reduction in energy, development of scaffolds, and lower medium cost, specifically in developing cheaper plant-based growth factors that are non GMO. Also product development is in its infancy.

Cultured meat is part of a movement towards more sustainable meat alternatives that also includes plant-based alternatives, insects and microbial protein. These sources should not be regarded as competition but as complementary products that target different types of consumers. In combination with other meat alternatives, cultured meat can lead to reduced production and consumption of conventional meat. 


\section{FAQs}

1. What is cultured meat?

Cultured meat (cell-based meat, cultured meat, artificial meat, clean meat, lab-grown meat or invitro meat) refers to animal cells grown in bioreactors. This method reduces the need to raise animals in farms.

2. How is cultured meat produced?

Stem cells acquired from animals are grown in bioreactors in an oxygen-rich cell culture medium. They go through maturation and differentiation into the skeletal muscle, fat, or connective tissues that make up meat. The differentiated cells are then harvested, prepared and packaged into final products.

3. What does the cell culture medium contain?

In the past, animal cells were grown on medium which included animal blood serum. This is now being replaced by very complicated, but well-defined media that contain basic nutrients such as amino acids, glucose, vitamins, and inorganic salts, and are supplemented with proteins and other growth factors.

4. Where do the growth factors for cultured meat culture medium come from?

All growth factors are currently produced in genetically modified microorganisms and isolated from them as a pure substance for use in the culture medium. These growth factors are identical to serum growth factors. The possibilities for the use of plant substances that can serve as growth factors are also being examined.

5. How long does it take to produce cultured meat products?

This process is expected to take between 2-8 weeks, depending on what kind of meat is being cultured. Less structured products like minced meats are easier to create than more structured products like steak.

6. Does cultured meat have the same nutritional value as conventional meat?

Cultured meat is made of the same cell types arranged in the same or similar structure as animal tissues, thus replicating the nutritional profiles of conventional meat muscle. Nutrients found in meat which are not synthesized by muscle cells must be supplied as supplements in the culture medium such as vitamin B12 and iron.

7. Are there antibiotics in cultured meat?

No, antibiotics are not used for the production of cultured meat.

8. Is cultured meat vegetarian/vegan?

It is possible to make a large amount of meat from a single stem cell. This means that far fewer animals will be needed for meat production. However, animals are still needed for the production of cultured meat.

9. Will cultured meat products taste and have the same sensory experience as conventional meat products?

Replicating all of the features (taste, colour, smell, texture, cooking properties) of conventional animal meat using cultured meat processes is likely to be challenging. First products mostly look like minced meat. However, there is ongoing research to improve on the end-product characteristics.

10. How will the cultured meat products be regulated?

To be granted regulatory approval and be labelled as a meat product, cultured meat must have similar nutritional profiles as their conventional counterparts. The nutritional data will have to be collected by companies and submitted to regulatory authorities prior to approval.

In Europe, food consisting of, isolated from, or produced from cell culture or tissue culture derived from animals, plants, micro-organisms, fungi or algae falls within the scope of the EU Novel Foods Regulation. Cultured meat would, therefore, require a pre-market authorisation, as well as approval by the European Food Safety Authority (EFSA), although it is not yet clear what type of nutritional and toxicological evidence EFSA would require to approve cultured meat. 
11. When will cultured meat products come to market?

In December 2020, the Singapore Food Agency approved the first lab-grown meat product, paving the way for commercialisation. Produced by US company Eat JUST, lab-grown "chicken bites" are now available to buy at a restaurant in Singapore. The cells for Eat Just's product are grown in a bioreactor and then combined with plant-based ingredients. Other examples are expected to follow within 1-2 years. Aside from the Singapore Food Agency (SFA), no other regulators have yet approved the sale of lab-grown meat products.

12. What might the first generation of cultured meat products be? The first generation of cultured meat products to come to market will potentially be less structured products such as minced meat, hamburger, sausages, and nuggets.

13. Will the cultured meat products be more expensive than conventional meat products? The first generation products are expected to come to the market at a premium price.

14. What are the major companies involved?

Eat Just (USA), SuperMeat (Israel), Memphis Meats (USA), Mosa Meat (NL), Meatable (NL), Aleph Farms (Israel), Finless Foods (USA), BlueNalu (USA), Future Meat Techologies (Israel).

15. How sustainable is cultured meat?

Cultured meat is sometimes presented as a good alternative for consumers who want to be more sustainable but do not wish to change their diet. However, cultured meat is only more sustainable than beef, but very similar to chicken and pork. Plant-based alternatives are much more sustainable. 


\section{Introduction}

Livestock production accounts for $14.5 \%$ of human-induced greenhouse gas emissions (Gerber et al., 2013). These are either emitted by animals themselves, for example as methane gas produced during ruminant digestion, or incur during feed production e.g. soy bean cultivation. Today, around $70-77 \%$ of the global agricultural land is used by the livestock sector and furthermore $33 \%$ of the global cropland is devoted to the production of feed crops for livestock production (Oonincx and de Boer, 2012; Post, 2012). Thereby, livestock production have been criticized due to both ethical (e.g. animal welfare) and environmental issues (e.g. climate change, land use) (Van der Weele and Driessen, 2013).

The world population is growing and wealth is increasing, which together result in increasing demand for animal products. Global food demand is projected to rise by $60 \%$ by 2050 (Alexandratos and Bruinsma, 2012). For sustainable supply of this demand complying with environmental and animal welfare issues, meat alternatives are required. Meat is an important source of high total protein and high quality protein including many essential amino acids. In order to meet the nutritional requirements of the world population, this needs to be supplied with meat replacers. For this purpose, different initiatives for meat substitutes have been taken. This includes plant-based, mycoproteinbased, and insect-based meat alternatives, but also the in vitro cultivation of meat cells (cultured meat). While the former listed initiatives are already in the market, this is not yet the case for cultured meat. A large number of companies are currently developing cultured meat products and market introductions might be expected in the coming years (Bomgardner, 2018; Choudhury et al., 2020).

Cultured meat (also referred to as cell-based meat, cultivated meat, artificial meat, clean meat, labgrown meat or in-vitro meat) are animal cells grown in cell culture in bioreactors, as opposed to on a farm. Cultured meat is made of the same cell types arranged in the same or similar structure as animal tissues, thus replicating the sensory and nutritional profiles of conventional meat. It is important to understand whether cultured meat provides environmental benefits and whether certain trade-offs exist.

In order to assess a product's environmental impact and identify potential hotspots within its life cycle, an internationally established approach is life cycle assessment (LCA). LCA is a standardized method with two main international standards i.e. ISO 14040:2006 and ISO 14044:2006 (ISO, 2006a, 2006b). LCA allows accounting for the environmental burdens generated in the life cycle of a product from the extraction of raw materials through production, use and disposal (ISO, 2006b). To date, only a very limited number of LCA studies on cultured meat are available. LCA studies allow identifying hotspots in cultured meat production and providing recommendations on where to focus in order to improve the environmental performance.

The purpose of this study is to review and analyse the potential of cultured meat as an alternative for the conventional livestock production based on existing sustainability studies. This includes comparison of results among different studies and also comparison of the environmental impact of cultured meat with different meat alternatives. Moreover, discussion concerning methodological choices (functional unit, scope, multifunctionality, impact categories, system boundaries) among different studies is included.

Furthermore, this study is intended to provide an overview of technical challenges faced in bringing cultured meat to commercialization, and recommendations for industry and policymakers in further development of cultured meat. The report also includes a FAQ (Frequently asked questions) section to provide basic information to general public who are interested to learn more about cultured meat. 


\section{Process, scale and costs of cultured meat production}

\section{$2.1 \quad$ Cultivation process}

The overall envisioned process for production of cultured meat involves the following five steps from single cells to a final food product:

(1) Inoculum preparation by cultivation of stem cells or cultivation of differentiated meat cells at small scale

(2) Proliferation stages in bioreactors

(3) Maturation/differentiation stage in bioreactors, including scaffolding and/or 3D-structuring

(4) Processing of cells and mixing with other cells and ingredients into a food product

(5) Packaging.

According to Specht, the upper scale for the production process of cultured meat is $20.000 \mathrm{~L}$, as this is the largest volume at which animal cells are cultured at this point (Specht, 2020). Specht describes a total of 4 stages that are required to go from inoculum to the cell maturation phase. Each of these stages have a duration of 10 days (40 days total) and occur in separate bioreactors. The feeding starts from $2.5 \mathrm{~mL}$ of cryo-preserved cells to inoculate (1) a $0.5 \mathrm{~L}$ reactor, with subsequent steps to (2) a $100 \mathrm{~L}$ reactor and (3) a $20.000 \mathrm{~L}$ reactor and finally (4) a maturation reactor. Multiple maturation reactors might be required per proliferation reactor. Depending on the assumptions for the required number of medium changes during cultivation a minimum of $20.000 \mathrm{~L}$ and a maximum of $140.000 \mathrm{~L}$ of medium is needed, with an average of $80.000 \mathrm{~L}$ for the low- and high-use scenarios for the 4 stages. The meat cell yield that can be expected from a $20.000 \mathrm{~L}$ run is $3.500 \mathrm{~kg}$ per batch.

Cost calculations for cultured meat have been made by Specht (Specht, 2020), based on the use of the Essential $8^{\mathrm{TM}}$ medium. This medium is sold at bench-scale at 400 USD per litre, but based on prices of individual components the price can be around 377 USD per litre. It has been suggested that the media required to produce $1 \mathrm{~kg}$ of cultured meat can feasibly achieve a cost as low as around 5.00 USD (assuming around $23 \mathrm{~L}$ will be needed per $\mathrm{kg}$ ), which is below the average cost per kilogram of most conventional meat (Specht, 2020).

Another recent report by Mattick and co-workers (Carolyn S Mattick et al., 2015) describes a more simple production process involving two steps (1) production of a (large) inoculum of stem cells $(1.000-1.500 \mathrm{~L})$ containing at least $10^{6}$ cells per $\mathrm{ml}$ and (2) final production of maturated cells in $15.000 \mathrm{~L}$ fermenters. This overall process lasts 11 days and yields approximately $150-200 \mathrm{~kg}$ meat per fermenter. The major costs of this process involve medium components and energy usage for preparation/sterilisation of the fermentation medium, stirring and aeration of the meat cells, cooling of the fermenter during fermentation and harvesting/concentrating and processing the cells after fermentation.

With respect to replacing current Dutch meat production with the described process by Mattick et al., an estimated 280.000 fermenters of $15.000 \mathrm{~L}$ would need to run continuously through the year to cover the meat consumption by the Dutch population. Taking into account that $75 \%$ of the Dutch meat production is exported, more than 1.000 .000 fermenters need to be in operation in the Netherlands to completely facilitate the current Dutch meat production.

It is the ultimate goal of the cultured meat industry to produce structured products besides unstructured products. This can be done via scaffolding but methods are being developed as well that do not require scaffolds. When using scaffolds these are preferably edible or can easily be removed. Common scaffold materials are based on collagen and cellulose or microcarriers of starch (Gaydhane et al., 2018) and microcarriers are being developed that are scalable in combination with stirred-tank bioreactors (Hanga et al., 2020). Cultivation without scaffolds is also under development, based on 
self-assembled layer-by-layer biofabrication that allows for the engineering of cell sheets and sheet stacking (Shahin-Shamsabadi and Selvaganapathy, 2021) or via 3D-printing (Handral et al., 2020).

\subsection{Limitations in cultured meat production ${ }^{1 *}$}

The basic principle of the cultured meat process starts with animal stem cells, currently isolated from sacrificed animals, but potentially taken via biopsy. These stem cells subsequently need to differentiate into muscle cells (or fat cells), and then enumerate multiple times to reach relevant amount of biomass. The below-listed specific conditions need to be met and specific limitations need to be dealt with to reach significant production of cultured meat.

- Animal biology tells us that an average animal cell can only multiply 30-40 times. This calculates to a maximal production of approximately $3.000-8.000 \mathrm{~kg}$ meat per isolated stem cell (biopt). If the total Dutch meat production would be replaced by cultured meat, 1 million biopts would be needed on annual basis, based on our annual Dutch meat production of over 3 billion $\mathrm{kg}$ of meat (own calculations). The amount of animals that this requires is determined by how many biopts you can take from one animal; if these can be stored; and how many cultivations can be run simultaneously.

- The process of MosaMeat depends on these biopts of stem cells from live - sacrificed animals. There is an alternative process, provided by Meatable, where a regular animal cell is transformed into a stem cell by molecular biology tools. In that, all the cultured meat that is produced based on the genetically modified (stem) cells should be considered genetically modified. Most promising regarding animal welfare is the use of muscle stem cells, which can also be obtained via a biopt (Choi et al., 2020).

- Cultured animal cells grow mostly only two-dimensionally, in layers/flakes/sheets. 3D cultivation is so far only done in model laboratory systems to mimic tissues in physiological studies. To achieve meaningful productivity of the cultured animal cells for meat production, very large surface areas are needed and these very large meat "flakes" are then combined to from a ground beef-like end product. These high-surface area are currently provided by socalled scaffolds which are materials that provide suitable surfaces for the animal cells to attach to. These scaffolds should be either edible or a process needs to be in place to separate the animal cell layers from the scaffolds. Processes for cells growing in suspension are in development as well.

- The layers or sheets of animal cells that are produced need assembly into a 3D structure. Various methods for assembly are proposed and researched such as spinning, cell layering, and 3D bioprinting (Jo et al, 2021).

- For the growth of the stem cells, the differentiation to muscle cells and the final enumeration to kg's of cultured meat, a maximum of 30-40 multiplications of cells are required. Since each multiplication requires around $24 \mathrm{hrs}$, a total production time of 30-40 days is needed.

- Various cultivation schemes have been described for production of cultured meat (see below), but with the largest reported production vessel of $20.000 \mathrm{~L}$, and with the estimated production of $3.000 \mathrm{~kg}$ meat per fermentation, more than 250.000 of these fermentations will need to be conducted annually to cover the overall Dutch meat consumption, and 4 times more to cover Dutch production.

\footnotetext{
* This chapter is based on various scientific publications and public reports on this topic (Carolyn S. Mattick et al., 2015; Specht, 2018; Tuomisto et al., 2014; Vergeer et al., 2021) and input from the expertise-group Animal Cell Cultivation at Wageningen University led by Dr Dirk Martens.
} 
- For running a regular cultured meat production process in a $20.000 \mathrm{~L}$ fermenter, approximately $100.000 \mathrm{~L}$ growth medium is needed for stem cell differentiation, cell maturation and enumeration. This cultivation medium is still very complicated (and expensive) requiring more than 80 different components, including some growth hormones that are still produced by modern biotechnology using genetically modified production cells. It has taken more than 20 years research to reach this stage from the original situation where large amounts of animal blood serum was used for cultivation of the animal cells.

- The combination of long cultivation times (30 - 40 days) and rich cultivation media (> 80 components) requires extreme measures to keep the meat cell cultivation from being contaminated by spoilage microorganisms. There are no examples of such fermentation processes in the food and/or pharma industry and the required investments are considerable.

- All these measures/limitations/requirements are needed for only the muscle protein part of the final meat. Similar approaches are needed to produce the meat fat and additional processes need to be developed/conducted to produce the flavour/colour/mouthfeel normally provided by animal blood. An alternative, but still quite futuristic, approach is the controlled growth/cultivation of whole muscle tissue, which includes fat cells and blood-containing arteries and veins.

\subsubsection{Cell types}

As described above, cultured meat is initiated from animal stem cells. These stem cells are isolated directly from the spine of animals (MosaMeat) or are produced from any body cell through genetic modification (Meatable). Subsequently, these stem cells can be multiplied 30-40 times to reach a productivity of $3.000-8.000 \mathrm{~kg}$ cultured meat in one production round. Although most information on this process is available for beef cells, it is expected that the process and limitations are similar for the other meat types - pork, poultry and fish.

\subsubsection{Medium requirements for cultured meat}

The medium requirements for cultivating meat cells can be dependent on the type of cultured cell line (e.g. muscle or fat cells from cow or fish), but can also be different when stem cells need to be differentiated into an unstructured product (for example a burger or sausage) or into a structured product (for example a steak or chicken breast) (O'Neill et al., 2021). Fetal bovine serum has been used in the past, but is currently being replaced by plant-based media to avoid use of animal materials in the process. In some media, fetal bovine serum and fetal calf serum are still additives (Arora, 2013).

The most commonly used medium in laboratory-scale cultured meat research is DMEM medium (Dulbecco's Modified Eagle Medium) or derivates thereof. These media are fully defined and easily replicated, including the content of inorganic salts, amino acids, and basic nutrients for culture growth. One such derived medium is Essential $8^{\mathrm{TM}}$ which is an animal-free medium (Specht, 2020) that lacks the animal component albumin without a replacement (Appendix 1). For cultivation of fish cells other types of media are currently used (Rubio et al., 2019). While albumin can be omitted from the medium, cell growth factors are essential for cell proliferation and differentiation and present most of the costs (99\%) of the medium. Growth factors for cell media are currently produced as recombinant forms using genetically modified microorganisms (Bhat and Fayaz, 2011). As a pH buffering system, the preference is for inexpensive bicarbonate systems (which allow for $\mathrm{CO}_{2}$ control) instead of more expensive buffer such as HEPES that are commonly used in animal cell culture. 


\subsubsection{Energy requirements of cultured meat}

A large part, estimated up to $75 \%$, of the energy costs for cultured meat comes from cooling during cell proliferation in bioreactors as a lot of heat is released during cell growth. There are some studies that propose that cell-based fish might be more sustainable than other types of cultured meat (e.g. minced meat, beef), as fish cell lines appear to be easier to grow with faster doubling times, more stable cell-lines, and lower oxygen requirements (Potter et al., 2020; Rubio et al., 2019). In addition, cell lines from water-based species have lower energy demands than those from land-based species, as cell lines can be grown at lower temperatures $\left(15-30^{\circ} \mathrm{C}\right.$ vs $\left.37^{\circ} \mathrm{C}\right)$ (Rubio et al., 2019). However, this argument doesn't hold when cooling is the main energy requirement.

\subsection{Summarizing technical bottlenecks}

As described in paragraph 2.1, there are various bottlenecks and hurdles that need to be overcome for cultured meat to develop to a mainstream, affordable, alternative to "real" meat. The current cultivation media are still too complex and expensive and still contain components that are produced by genetically modified organisms. The two-dimensional growth of the meat cells requires very high surface areas provided by scaffolds and very large numbers of cultivation reactors. The whole process needs almost unrealistic sterility measures for extended cultivation times in large volumes to prevent infections. Finally, after these issues are overcome essential elements such as fat, colour, flavour and mouthfeel/juiciness will still be missing.

\subsection{Other processed meat replacers}

Many vegetarians or vegans get their protein intake from plant products like legumes or nuts. However, many consumers, including a growing number of so-called flexitarians, appreciate the look and mouthfeel of meat. Below some alternatives that aim to get close to meat are discussed. Some of the challenges that the cultured meat development faces have been tackled in those products before.

\subsubsection{Plant-based burgers}

Many types of plant-based burgers are available on the market, for which the production process in general involves three steps (Rubio et al., 2020): (i) protein isolation and functionalization, where the desired plant proteins are extracted from plants (ii) formulation, in which the mixing of plant proteins with other ingredients such as food adhesives, plant-based fat and flour takes place (iii) processing, where the mixture gets e.g. kneaded or pressed, with possible extrusion as the main method to create a layered texture that mimics the fibrous structure of meat. One high-end burger is the Impossible burger, which mimics the blood-like juice from meat, by adding plant-based GMO Heme into their product. This illustrates that high cost for certain components and the fear of consumers rejecting GMO products may be overcome.

\subsubsection{Quorn}

Quorn is a well-known and widely available mycoprotein-based product based on the filamentous fungus Fusarium venenatum (Whittaker et al., 2020; Wiebe, 2002). The production scale of this mycoprotein is 10.000-14.000 ton mycoprotein per year (reference year 2017). The current production process consists of ten phases: (i) cultivation of mycelium is performed in three fermentation reactors of $155 \mathrm{~m}^{3}$ reactors each ( $465 \mathrm{~m}^{3}$ total) and uses as a substrate a starch-derived glucose-syrup which is delivered by heated tankers (Whittaker et al., 2020) (ii) after fermentation the entire biomass is transferred to a separate stirred reactor to perform RNA reduction by a 15 min steam treatment at $68^{\circ} \mathrm{C}$ (iii) the treated biomass is then centrifuged at $90^{\circ} \mathrm{C}$ and (iv) subsequently cooled down in a chiller $\left(90^{\circ} \mathrm{C} \rightarrow 4^{\circ} \mathrm{C}\right)$. The mycoprotein is then further processed by $(\mathrm{v})$ mixing with binders and flavours ( $\mathrm{vi}$ ) shaping (vii) steaming (viii) chilling (ix) texturizing and (x) packaging (Finnigan, 2011; Whittaker et al., 2020). 
The whole process is quite elaborate, although probably not as elaborate as that for cultured meat. A substantial part of the energy use is in the processing of the mycoprotein into the Quorn products (Finnigan et al., 2016). This illustrates the importance of incorporating also product assembly and not only cell cultivation when looking at cost and sustainability.

\subsubsection{Microbial biomass}

Microbial fermentation is emerging as a new technology to provide (large amounts of) protein for both feed and food applications. Cultivation is much simpler than that for cultured meat. Full-grown microbial cultures can be achieved in $24 \mathrm{~h}$, instead of the 11 days described above for cultured meat production. Cultivation can be conducted at much larger scale (100.000 L fermenters and larger) using cheap cultivation media such as various abundantly available agri-food side streams. The microbial biomass typically contains $50+\%$ protein. It's suitability for human consumption has already been established through existing food products such as Quorn (see above, 100\% Fusarium biomass), Tempeh (containing more than 50\% Rhizopus biomass) and other traditional fermented food products such as Natto which is mostly composed of Bacillus subtilis biomass. Many more microbial protein sources are potentially available when considering currently operating fermentation processes. Global bioethanol production alone, for , beverage and chemical/fuel application, generates almost $10^{11} \mathrm{~kg}$ yeast protein per year which is under-utilized and could provide a good protein basis for alternative meat products. Utilizing these side-streams can be a sustainable alternative to primary

(bio)production. 


\section{Sustainability of cultured meat}

\subsection{LCA methodology}

LCA assesses the environmental impacts associated with a product throughout its life cycle. Following ISO $14040 / 14044$ standards (ISO, 2006a, 2006b), LCA is carried out in four phases:

1. Goal and scope definition

2. Inventory analysis

3. Life cycle impact assessment

4. Interpretation.

In the first phase, the goal of the study is described and the scope is defined which outlines the functional unit, system boundary, product systems, method for handling multifunctionality and temporal, geographical and technical coverage. In the inventory analysis, inventory data is compiled of elementary flows (inputs and outputs) related to each unit process within a product system. The data is then related to the functional unit. In the life cycle impact assessment (LCIA) phase of LCA, the inventory data are assigned to the corresponding impact categories and then converted into quantitative environmental impacts using characterization factors. In the interpretation phase, set of conclusions and recommendations are drawn.

\subsection{LCA studies on cultured meat production}

To date, only a very limited number of LCA studies on cultured meat are available. All of them are prospective studies conducted at early stage of development and projecting production at commercial scale in the future. The first ever LCA study to be published on this topic was conducted by Tuomisto and de Mattos in 2011 where a cyanobacteria-based feedstock was considered (Tuomisto and de Mattos, 2011). In 2014, Tuomisto et al. amended this previous study by considering alternative feedstocks of wheat or corn as energy and nutrient source (Tuomisto et al., 2014). Later in 2015, Mattick et al. published a study where serum free media for muscle cell cultivation was used with soy hydrolysate as feedstock (Carolyn S. Mattick et al., 2015). Moreover, Smetana et al. published a study in 2015 comparing the environmental performance of meat substitutes (plantbased, mycoprotein-based, lab-grown, insect-based and dairy-based) (Smetana et al., 2015). For cultured meat, the study relied on data of Tuomisto and de Mattos (Tuomisto and de Mattos, 2011). Furthermore, several review papers have been published on this topic including findings of these LCA studies (Chriki and Hocquette, 2020; Jiang et al., 2020; Santo et al., 2020; Treich, 2021). Also, for the Good Food Institute (GFI) nova institute reviewed the findings of the LCA studies and provided recommendations for a future LCA study in 2019 (Scharf et al., 2019). Recently, in 2021 CE Delft carried out a LCA study using for the first time primary data from companies active in cultured meat production and in the supply chain (P Sinke and Odegard, 2021). This study was commissioned by GAIA and the GFI. In parallel CE Delft also carried out a techno-economic assessment (Vergeer et al., 2021). GFI later published both a technical and a policy summary based on the findings of these two CE Delft studies (Swartz, 2021a, 2021b). An overview of LCA studies on cultured meat is provided in Table 1. 
Table 1

Overview of LCA studies on cultured meat

\begin{tabular}{|l|l|l|l|}
\hline Reference & Year & Title & Funding from \\
\hline $\begin{array}{l}\text { (Tuomisto and de } \\
\text { Mattos, 2011) }\end{array}$ & 2011 & $\begin{array}{l}\text { Environmental impacts of cultured } \\
\text { meat production }\end{array}$ & New Harvest (USA) \\
\hline (Tuomisto et al., 2014) & 2014 & $\begin{array}{l}\text { Environmental impacts of cultured } \\
\text { meat: alternative production scenarios }\end{array}$ & $\begin{array}{l}\text { Joint Research Centre } \\
\text { (EU) }\end{array}$ \\
\hline $\begin{array}{l}\text { (Carolyn S. Mattick et } \\
\text { al., 2015) }\end{array}$ & 2015 & $\begin{array}{l}\text { Anticipatory Life Cycle Analysis of In } \\
\text { Vitro Biomass Cultivation for Cultured } \\
\text { Meat Production in the United States }\end{array}$ & $\begin{array}{l}\text { Arizona State } \\
\text { University (USA) }\end{array}$ \\
\hline $\begin{array}{l}\text { (P Sinke and Odegard, } \\
\text { 2021) }\end{array}$ & 2021 & $\begin{array}{l}\text { LCA of cultured meat } \\
\text { GAIA (BE) and GFI } \\
\text { (USA) }\end{array}$ \\
\hline
\end{tabular}

\subsection{Review of the goal and scope of reviewed studies}

\subsubsection{Goal}

The goal of the conducted LCA studies is to estimate the potential environmental impacts of commercial scale cultured meat production and compare them with conventionally produced protein products (meat and plant based).

They are all ex-ante, prospective studies, where a future commercial scale production facility is modelled. An attributional approach is used for the LCA studies where it is intended to evaluate and/or compare products and identify the most impacting process parameters.

\subsubsection{Functional unit}

The functional unit is the quantified description of the function of a product that serves as the reference basis for all calculations regarding impact assessment. In Table 2, the functional unit used in the reviewed studies is provided.

Table 2
\begin{tabular}{|l|l|}
\hline Reference & Functional unit \\
\hline $\begin{array}{l}\text { (Tuomisto and de } \\
\text { Mattos, 2011) }\end{array}$ & $\begin{array}{l}1.000 \mathrm{~kg} \text { of cultured meat with } 19 \% \text { protein content (on wet basis) and } 30 \% \\
\text { dry matter content }\end{array}$ \\
\hline $\begin{array}{l}\text { (Tuomisto et al., } \\
2014)\end{array}$ & $\begin{array}{l}1.000 \mathrm{~kg} \text { of cultured meat with } 19 \% \text { protein content (on wet basis) and } 30 \% \\
\text { dry matter content }\end{array}$ \\
\hline $\begin{array}{l}\text { (Carolyn S. } \\
\text { Mattick et al., } \\
2015)\end{array}$ & $\begin{array}{l}1 \mathrm{~kg} \text { of Chinese hamster ovary cell biomass with } 7 \% \text { protein content (on wet } \\
\text { basis) and } 17 \% \text { dry matter content }\end{array}$ \\
\hline $\begin{array}{l}\text { (P Sinke and } \\
\text { Odegard, 2021) }\end{array}$ & $\begin{array}{l}1 \mathrm{~kg} \text { of high-protein product (i.e. cultured meat, conventional meat or a plant- } \\
\text { based meat alternative that is eaten for its high protein content) with } 18-25 \% \\
\text { protein content (on wet basis) and 20-30\% dry matter content }\end{array}$ \\
\hline
\end{tabular}

The final cultured meat product considered in these studies is a non-structured, ground meat type product in terms of textual characteristics.

\subsubsection{Temporal, geographical and technological coverage}

Regarding temporal and technological coverage, the reviewed studies considered future projection into commercial large-scale production facility with suitable bioreactors. CE Delft selected the year 2030 whereas the others didn't indicate a specific timeframe. In the initial study of Tuomisto and de Mattos, three different production locations were considered: Spain, California and Thailand (Tuomisto and de Mattos, 2011). Modelling energy generation in Spain and California, average European and U.S. electricity mix were used respectively. In the 2014 study, only representative European production was considered (Tuomisto et al., 2014). Mattick et al. 
considered cultured meat production in the United States (Carolyn S. Mattick et al., 2015). In the CE Delft study, the location for cultured meat production is not specifically described but it is considered international (P Sinke and Odegard, 2021). The cultured meat production companies that provided data for the LCA study and their locations are Aleph Farms (Israel), Avant Meats (Hong Kong), Mosa Meat (the Netherlands), Shiok Meats (Singapore) and Wild Type (U.S.).

\subsubsection{Product systems}

The product system is the collection of all activities within the system boundary that are associated with the functional unit. In comparative LCA, several product systems can be considered and compared. In the reviewed studies, the cultured meat product system is compared with conventional meat product systems of beef, pork and chicken (Carolyn S. Mattick et al., 2015; P Sinke and Odegard, 2021; Tuomisto et al., 2014; Tuomisto and de Mattos, 2011). Mattick et al. considered representative production of these conventional meat products in the United States (Carolyn S. Mattick et al., 2015). Whereas, Tuomisto and de Mattos used data representative of European production and also included sheep in the comparison (Tuomisto and de Mattos, 2011). Furthermore, they made an additional comparison per kg protein including also other animal and plant-based protein sources (fish, eggs, milk, pulses) based on data from Nijdam et al. (Nijdam et al., 2012; Tuomisto et al., 2014). In the CE Delft study, for the production of conventional meat products the lower end of environmental impact is considered with data representative of intensive, West-European production with circular agricultural system is used. Furthermore, Meatless (a plant based texturized meat replacement product) and tofu are also included in the comparison (P Sinke and Odegard, 2021).

\subsubsection{System boundary}

The system boundary sets which processes are part of the product system and are included in the assessment. Figure 1 provides a simplified flow diagram of cultured meat production which involves mainly four stages: feedstock media production, cell growth, final product manufacturing, and distribution and use. The system boundary of all reviewed studies covers the processes from cradle to factory gate (first two stages indicated with red dashed rectangle in Figure 1). This includes resource extraction, energy and nutrient production that is needed to produce the cultured meat, from all parts of the production process (including nutrition medium) and transport between processes. The distribution, use and disposal stages of the meat products are not included in the system boundary of the reviewed studies. As seen in Table 3, studies show wide differences in the processes included within the system boundary of their studies.

Stage 1-Feedstock media: This stage considers resource extraction and production of sources of energy and nutrients for cell culture medium production. Tuomisto and de Mattos used cyanobacteria hydrolysate as the nutrient and energy source for muscle cell growth. Therefore, the processes included were cyanobacteria cultivation and harvest followed by sterilisation and hydrolysis of cyanobacteria (Tuomisto and de Mattos, 2011). In the later study, Tuomisto et al. considered also alternative feedstocks of wheat or corn as energy and nutrient source (Tuomisto et al., 2014). Therefore, the processes of cultivation and harvest of corn and wheat followed by sterilisation and hydrolysis were included in the system boundaries.

In Mattick et al. glucose from corn starch was used as energy source and soy hydrolysate was used as nutrients source for muscle cell growth. Therefore, the processes included in Mattick et al. study were, corn and soybean cultivation and harvest followed by corn wet milling and saccharification of corn starch to glucose and soybean milling and hydrolysis (Carolyn S. Mattick et al., 2015). Furthermore, the production of amino acid glutamine from fermentation of glucose was included in the system boundaries. Similarly, in the CE Delft study, soy hydrolysate was used as nutrient source and corn is converted into glucose as energy source.

For the medium production, in the analysis of Tuomisto et al., the modelling of amino acids, growth factors and vitamins production were excluded. Whereas, Mattick et al. modelled input of water, vitamins, minerals and other amino acids. The growth factor production was excluded also from their analysis. In the CE Delft study all (amino acid, minerals, vitamins, growth factors and water) were 
included. They considered amino acid production from hydrolysate as well as microbially or synthetically produced amino acids (P Sinke and Odegard, 2021).

Stage 2-Cell growth: This stage includes proliferation where cells are multiplied followed by differentiation and maturation where the cells can be seeded on to a scaffold for structural support. For scaffold, Mattick et al. considered microcarrier beads made from corn starch and CE Delft considered an edible plant based scaffolding material in the form of hydrogel. Whereas, scaffold material was excluded by Tuomisto.

The cleaning of the bioreactor and facility energy requirements were considered by Mattick et al. and in the CE Delft study and were excluded by Tuomisto. While the bioreactor production was considered by Tuomisto et al. and in the CE Delft study and was excluded by Mattick. Only, Mattick et al. considered a medium change between proliferation and differentiation phases. Only in CE Delft study wastewater treatment was included. The spent media recycling and the treatment of other waste products were excluded from all studies.

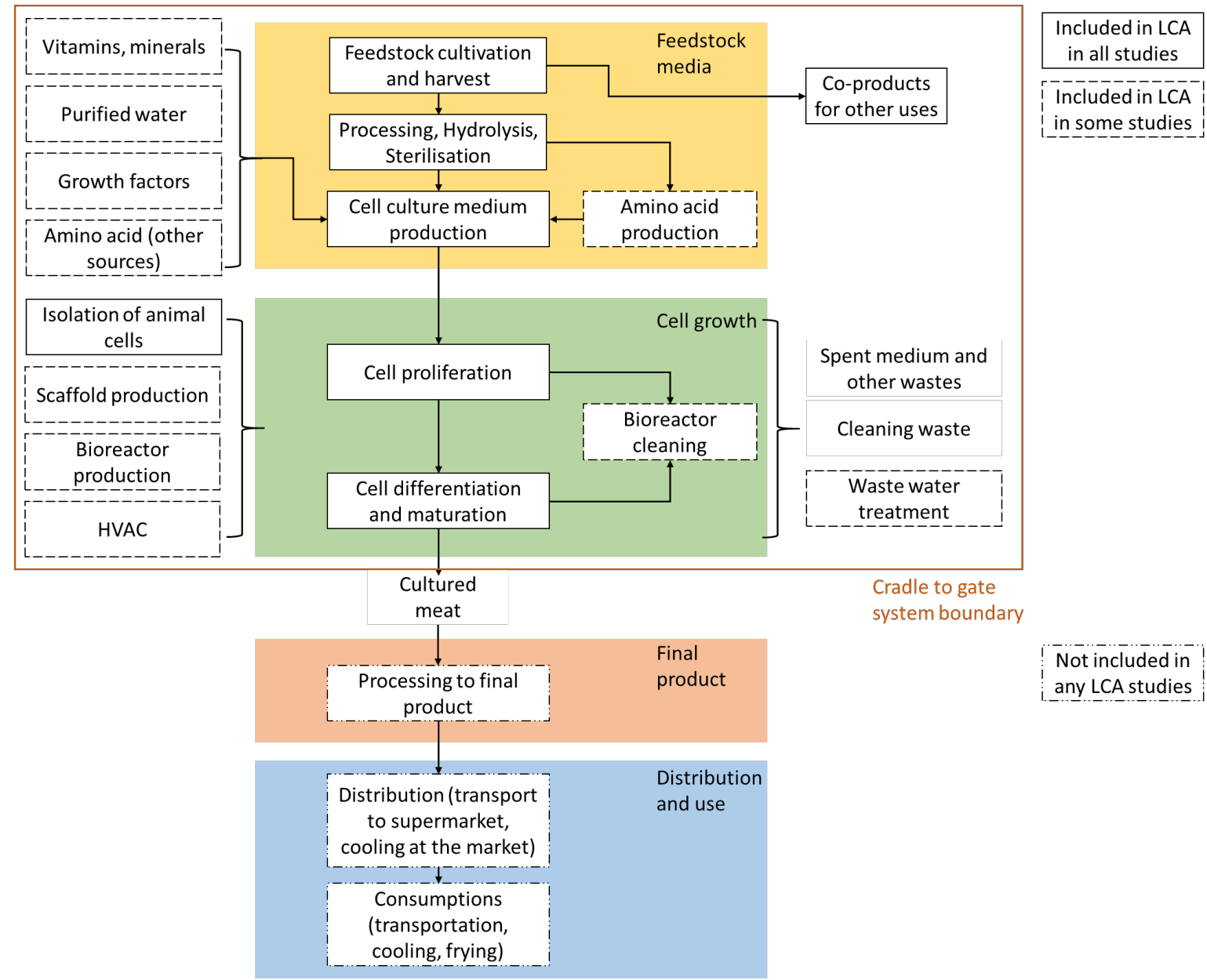

Figure $1 \quad$ Simplified flow diagram of cultured meat production 


\begin{tabular}{|c|c|c|}
\hline Reference & Stage 1- Feedstock media & Cell growth \\
\hline $\begin{array}{l}\text { (Tuomisto } \\
\text { and de } \\
\text { Mattos, } \\
\text { 2011) }\end{array}$ & $\begin{array}{l}\text { Cyanobacteria hydrolysate as nutrient and } \\
\text { energy source } \\
\text { Included: Cultivation, harvest, hydrolysis } \\
\text { Excluded: Modelling of amino acids, growth } \\
\text { factors and vitamins production }\end{array}$ & $\begin{array}{l}\text { Included: Bioreactor production } \\
\text { Excluded: Scaffold, cleaning, HVAC, } \\
\text { wastewater treatment }\end{array}$ \\
\hline $\begin{array}{l}\text { (Tuomisto et } \\
\text { al., 2014) }\end{array}$ & $\begin{array}{l}\text { What, corn and cyanobacteria as nutrient } \\
\text { and energy source } \\
\text { Included: Cultivation, harvest and } \\
\text { hydrolysis } \\
\text { Excluded: Modelling of amino acids, growth } \\
\text { factors and vitamins production }\end{array}$ & $\begin{array}{l}\text { Included: Bioreactor production } \\
\text { Excluded: Scaffold, cleaning, HVAC, } \\
\text { wastewater treatment }\end{array}$ \\
\hline $\begin{array}{ll}\text { (Carolyn S. } \\
\text { Mattick et } \\
\text { al., 2015) }\end{array}$ & $\begin{array}{l}\text { Glucose (corn starch) energy source, soy } \\
\text { hydrolysate nutrient source } \\
\text { Included: Cultivation, harvest, } \\
\text { saccharification/ hydrolysis + amino acid, } \\
\text { vitamins and minerals } \\
\text { Excluded: Growth factor }\end{array}$ & $\begin{array}{l}\text { Included: Scaffold (microcarrier beads } \\
\text { from corn starch), cleaning, HVAC } \\
\text { Excluded: Bioreactor production, } \\
\text { wastewater treatment }\end{array}$ \\
\hline $\begin{array}{l}\text { (P Sinke and } \\
\text { Odegard, } \\
\text { 2021) }\end{array}$ & $\begin{array}{l}\text { Glucose (corn starch) energy source, soy } \\
\text { hydrolysate nutrient source } \\
\text { Included: Cultivation, harvest, } \\
\text { saccharification/ hydrolysis + amino acid, } \\
\text { vitamins and minerals, growth factors }\end{array}$ & $\begin{array}{l}\text { Included: Scaffold (hydrogel), cleaning, } \\
\text { HVAC, bioreactor production, } \\
\text { wastewater treatment }\end{array}$ \\
\hline
\end{tabular}

\subsubsection{Method for handling multifunctionality}

If a process has more than one output (i.e. multifunctionality), a procedure to distribute the impacts over all outputs need to be applied. Tumosto and de Mattos allocated all of the energy inputs for sterilization, hydrolysis, and fermentation to cultured meat. They used mass allocation for allocating the cyanobacteria production to cultured meat and other side products (Tuomisto and de Mattos, 2011). For the alternative feedstock sources of wheat and corn used in the later study (Tuomisto et al., 2014), data was based on Williams et al. (Williams et al., 2006) where economic allocation is applied to distribute the burdens between co-products. In Mattick et al., environmental impacts were allocated to inputs and their coproducts on a gross chemical (calorific) energy basis. This was applied for the soybean meal and corn starch used as feedstock (Carolyn S. Mattick et al., 2015).

For carrying out comparison with conventional meat products, the LCA results reported in live animal weights were converted to edible meat using conversion factors (beef $37 \%-43 \%$, pork $56 \%$, lamb $34 \%$ and poultry 56\%) (Carolyn S. Mattick et al., 2015; Tuomisto et al., 2014). Economic allocation was used to allocate the impacts between the edible and non-edible parts of the animal based on relative market value. Tuomisto et al. used $90 \%$ allocation of economic value associated with edible part (Tuomisto et al., 2014), whereas Mattick et al. used different value for different type of animal in the range of $88.5-92.4 \%$ (Carolyn S. Mattick et al., 2015). In CE Delft study, Agri-footprint database with economic allocation was used for the data for conventional meat products (P Sinke and Odegard, 2021).

\subsubsection{Impact assessment method and impact categories}

This step of LCA analysis includes identifying the impact categories relevant for the study and selecting a methodology to calculate the impact categories which are used in translating the inventory data into a number of potential environmental impacts. All reviewed studies considered global warming potential, energy use, and land use as relevant impact categories. An overview of the impact categories and impact assessment methods used in the reviewed LCA studies is provided in Table 4. 
For global warming potential (GWP), Tuomisto et al. applied the IPCC 2007 method, Mattick used the CML 2001 method based on IPCC 2007, and the CE Delft study used the ReCiPe 2016 method where the GWP is based on IPCC 2013. For energy use, Tuomisto et al. converted the electricity and fuels used to primary energy using conversion factors (Tuomisto et al., 2014) and Mattick et al. used Cumulative Energy Demand method (Carolyn S. Mattick et al., 2015). For land use, Tuomisto et al. assessed the land requirement in hectare and Mattick et al. used the Ecological Footprint Method which quantifies direct land occupation associated with human activities (Carolyn S. Mattick et al., 2015). CE Delft study assessed land use based on ReCiPe 2016 method, where it is expressed in $\mathrm{m}^{2} \mathrm{yr}$ annual crop equivalents). Indirect land use impacts are excluded from the studies.

Beside Mattick et al., all reviewed studies also included the water use category. Tuomisto and de Mattos used methodology adopted from Mila i Canals et al. (Milà I Canals et al., 2009). The water footprint included the use of blue (surface and groundwater) and green water (rainwater). Both direct and indirect water use is included. Direct water use refers to the direct water inputs used in the process, whereas indirect use refers to the water needed for production of energy sources used in the process (Tuomisto and de Mattos, 2011). Tuomisto et al. updated the method considering only blue water and using country specific (Spain) water scarcity characterization factor based on Kounina et al. (Kounina et al., 2013). The CE Delft study assessed water use based on ReCiPe 2016 method, where blue water use is considered.

Additionally, Mattick et al. included impact category of eutrophication of CML 2001 method. Whereas, the CE Delft study used the ReCiPe 2016 method with, in total, 17 (midpoint) impact categories (Huijbregts et al., 2017). Furthermore, they calculated weighted ReCiPe single score in their analysis to represent the total environmental impact (P Sinke and Odegard, 2021) seen in Table 5. The different choice of impact assessment methods chosen by the studies hinder comparability of results.

\begin{tabular}{|c|c|}
\hline $\begin{array}{l}\text { Imp } \\
\text { stuc }\end{array}$ & tegories and impact assessment methods used in the reviev \\
\hline Reference & Impact categories and assessment methods \\
\hline $\begin{array}{l}\text { (Tuomisto and de } \\
\text { Mattos, 2011) }\end{array}$ & $\begin{array}{l}4 \text { impact categories: GWP (IPCC 2007), Energy use, Land use and Water } \\
\text { use (based on Mila i Canals et al. (Milà I Canals et al., 2009)) }\end{array}$ \\
\hline $\begin{array}{l}\text { (Tuomisto et al., } \\
\text { 2014) }\end{array}$ & $\begin{array}{l}4 \text { impact categories: GWP (IPCC 2007), Energy use, Land use and Water } \\
\text { use (updated methodology based on Kounina et al. (Kounina et al., 2013)) }\end{array}$ \\
\hline $\begin{array}{l}\text { (Carolyn S. Mattick } \\
\text { et al., 2015) }\end{array}$ & $\begin{array}{l}4 \text { impact categories: GWP (CML 2001), Energy use (Cumulative Energy } \\
\text { Demand), Land use (Ecological Footprint) and Eutrophication (CML 2001) }\end{array}$ \\
\hline $\begin{array}{l}\text { (P Sinke and } \\
\text { Odegard, 2021) }\end{array}$ & 17 impact categories of ReCiPe 2016 method (Huijbregts et al., 2017) \\
\hline
\end{tabular}


Table 5

ReCiPe method used in the CE Delft study (from Sinke and Odegard, 2021)

\begin{tabular}{|c|c|c|c|}
\hline Midpoints & Unit & Endpoints & Single Score \\
\hline Global warming & $\mathrm{kg} \mathrm{CO}$-eq. & \multirow{8}{*}{$\begin{array}{l}\text { Human Health } \\
\text { (DALY) }\end{array}$} & \multirow{19}{*}{$\mathrm{mPt}$} \\
\hline Stratospheric ozone depletion & kg CFC11-eq. & & \\
\hline Ionizing radiation & kBq Co-60-eq. & & \\
\hline Ozone formation. Human health & $\mathrm{kg} \mathrm{NO}$-eq. & & \\
\hline Fine particulate matter formation & $\mathrm{kg} \mathrm{PM} 2.5$-eq. & & \\
\hline Human carcinogenic toxicity & $\mathrm{kg} 1,4-\mathrm{DCB}$ e & & \\
\hline Human non-carcinogenic toxicity & $\mathrm{kg} 1,4-\mathrm{DCB}$ e & & \\
\hline Water consumption & $\mathrm{m}^{3}$ & & \\
\hline Global warming & $\mathrm{kg} \mathrm{CO}$-eq. & \multirow{9}{*}{$\begin{array}{l}\text { Ecosystems } \\
\text { (species. year) }\end{array}$} & \\
\hline Ozone formation. Terrestrial ecosystems & $\mathrm{kg} \mathrm{NO}$-eq. & & \\
\hline Terrestrial acidification & $\mathrm{kg} \mathrm{SO}$-eq. & & \\
\hline Freshwater eutrophication & $\mathrm{kg} \mathrm{P}$ eq. & & \\
\hline Terrestrial ecotoxicity & kg 1,4-DCB e & & \\
\hline Freshwater ecotoxicity & $\mathrm{kg} 1,4-\mathrm{DCB}$ e & & \\
\hline Marine ecotoxicity & $\mathrm{kg} 1,4-\mathrm{DCB}$ e & & \\
\hline Land use & $\mathrm{m}^{2} \mathrm{a}$ crop eq. & & \\
\hline Water consumption & $\mathrm{m}^{3}$ & & \\
\hline Mineral resource scarcity & kg Cu eq. & \multirow{2}{*}{ Resources (\$) } & \\
\hline Fossil resource scarcity & kg oil eq. & & \\
\hline
\end{tabular}

\subsection{Review of inventory data used in reviewed studies}

After the goal and scope definition, the second phase of an LCA is the Life Cycle Inventory (LCI) analysis which involves creating an inventory of flows from and to nature for a product system. The input and output data (resource use and emissions) is collected for each process within the system boundary. The inventory data is then related to or expressed per functional unit. The foreground system should aim at using primary data from the producer and for the background system (e.g. raw material or energy supply) secondary data from third-party databases can be used. Since cultured meat production is yet at early stage of development, the inventory data is mostly based on lab scale data and on simulations models for hypothetical large-scale production. The input data of the different studies can be found in Appendix 2.

\subsection{Review of impact assessment results}

Life cycle inventory analysis is followed by a life cycle impact assessment where the inventory data is converted into a set of potential impacts. The impact categories selected in the reviewed studies and their methods were highlighted in section 3.3.7. All reviewed studies considered global warming potential, energy use and land use. The results for these impact categories from the reviewed studies are described below.

\subsubsection{Global Warming Potential}

In Figure 2, GWP results of the reviewed LCA studies are presented. For Tuomisto et al. (2014), the lowest impact is seen for cyanobacteria (best case scenario) and a higher impact is seen for wheat (worst case scenario), which are selected to show the range of results in Figure 2. When comparing the Tuomisto et al. (2014) results with the results of Tuomisto and Teixeira de Mattos (2011) for cyanobacteria feedstock, the difference lies in the muscle cell cultivation. This is due to the higher energy input of cultured meat used in this study which is explained by more accurate modelling of the bioreactor and inclusion of bioreactor heating requirement. When comparing the cyanobacteria (best case scenario) and wheat (worst case scenario), a higher impact is seen for production of feedstock and its processing due to higher emissions associated with wheat cultivation compared to cyanobacteria. The other difference lies in the higher energy requirement of muscle cell cultivation for worst case scenario due to lower cell density. The difference in the GWP results, stem mainly from the difference in processes included within system boundaries (see Table 3 ). 
Tuomisto did not include basal media production (amino acids, growth factors, vitamins and minerals), scaffold, energy requirements of production facility (heating, ventilation, and air conditioning (HVAC)) or bioreactor cleaning. It is seen that especially the basal media production and bioreactor cleaning have significant impacts resulting in higher emissions seen for Mattick study. The significance of basal media production was also observed in the CE Delft study. Especially due to the microbial or synthetic amino acid production and recombinant protein production which have a relatively high demand for feedstock, energy, water and chemicals.

In the CE Delft study, a conservative approach for cooling was chosen (active cooling of the reactors were modelled) to make sure the environmental impact was not underestimated. This is estimated to result in GWP about $8 \mathrm{gCO}_{2} \mathrm{eq} / \mathrm{kg}$ cultured meat. Whereas the other studies considered using ambient temperature cooling water and this impact is therefore not included. This results in significant variation between the results from the previous studies. In CE Delft study an important option for improvement of GWP is seen by shifting to sustainable energy. Overall, it was seen that production of scaffolds, production of equipment/reactor and HVAC of the facility showed minor contributions to the environmental impacts.

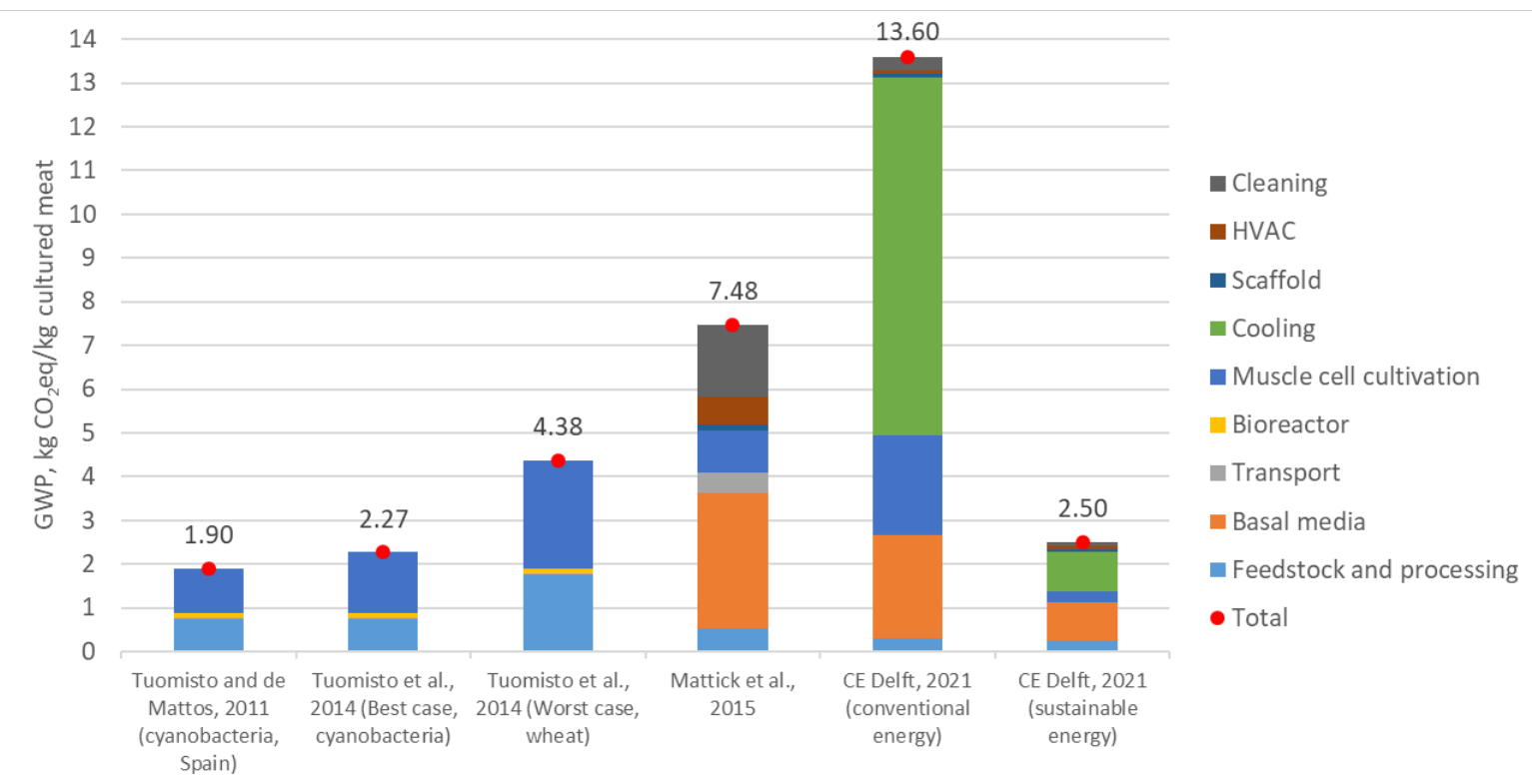

Figure 2 Global warming potential (GWP) of cultured meat

\subsubsection{Energy use (Cumulative Energy Demand)}

The results of energy use of cultured meat from reviewed studies are provided in Figure 3. A similar trend to GWP results is observed. For the CE Delft study, a total is given but a specific breakdown of energy use is not provided. From the contribution analysis of energy use, it can be deducted that the main driver is cooling system for the bioreactor where active cooling was considered. This results in the higher energy use reported in the study, even considering the shift to sustainable energy. It can be concluded that the variation in the results among studies is mainly due to the processes included in the system boundaries and the further detailed consideration of inventory data. 


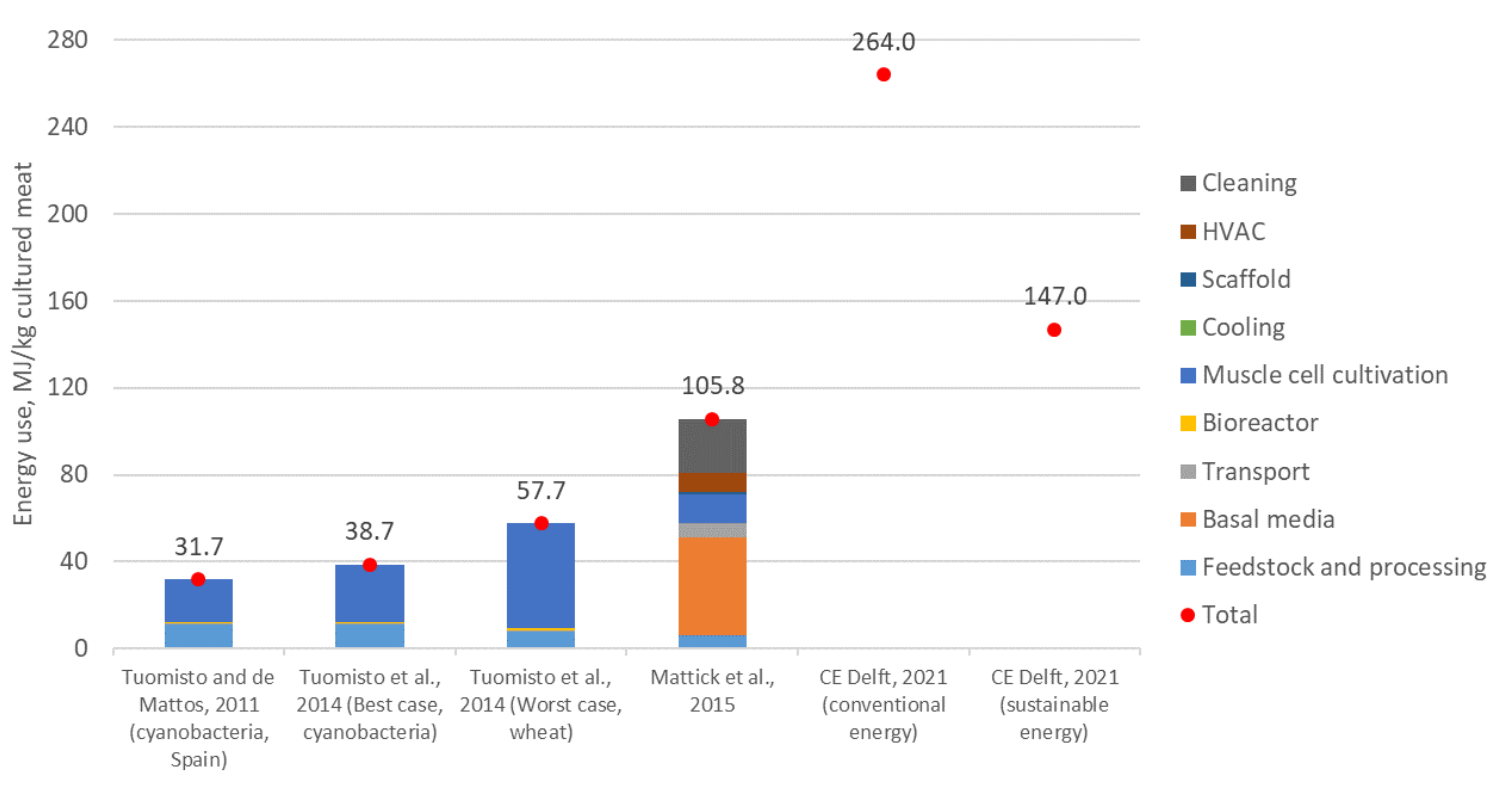

Figure $3 \quad$ Energy use of cultured meat

\subsubsection{Land use}

The land requirements for producing feedstock for cultured meat production vary according to the type of feedstock used in Tuomisto et al. (2014) being 0.46, 2.60 and $2.82 \mathrm{~m}^{2} \mathrm{a} / \mathrm{kg}$ cultured meat for cyanobacteria, wheat, and corn respectively. Land use requirements for Mattick et al. (2015) is $5.5 \mathrm{~m}^{2} \mathrm{a} / \mathrm{kg}$ cultured meat. The higher impact is due to additional feedstock inputs considered in this study: for the production of glucose, soy hydrolysate, microcarrier beads from corn starch and basal media. In the CE Delft study a similar feedstock input to Mattick et al (2015) is considered (glucose, soy hydrolysate, amino acids). However, significantly lower land use is estimated $\left(1.8 \mathrm{~m}^{2} \mathrm{a} / \mathrm{kg}\right.$ cultured meat). This can be due to the different impact assessment methods used in the studies: Mattick et al. used Ecological Footprint v1.01 and CE Delft used ReCiPe 2016.

\subsubsection{Water use}

As described in section 3.3.7, water use was not assessed in Mattick et al. (2015) and different methods were used to calculate water use in the other three studies. Hence no direct comparison of the results is possible. Tuomisto and de Mattos (2011) included both green and blue water use with the total ranging from $0.37-0.52 \mathrm{~m}^{3} / \mathrm{kg}$ cultured meat. The majority of water use (more than $80 \%$ ) is for replacing the evaporation loss in cyanobacteria cultivation. The rest is used for muscle cell cultivation. In Tumosto et al. (2014), only blue water is included and estimated as $0.33,0.52$ and $0.84 \mathrm{~m}^{3} / \mathrm{kg}$ cultured meat for wheat, cyanobacteria, and corn respectively where the difference lies in the requirements in cultivation of feedstocks. In the CE Delft study also only blue water (surface and groundwater) was considered and significantly lower water use is estimated $\left(0.042 \mathrm{~m}^{3} / \mathrm{kg}\right.$ cultured meat). This can be due to the different impact assessment methods used in the studies. In the CE Delft study water is used for feedstock cultivation, for cell culture medium, and for cleaning of the bioreactors. For the sustainable energy scenario the CE delft study reports higher water use than conventional energy scenario. This is traced in their report to the production of electronics-grade silicon for solar cells which in its inventory is seen as a water-intensive process. However, the authors note that this can be an out-dated inventory and the results should only be taken as a guideline.

\subsubsection{Other impact categories}

In the CE Delft study the ReCiPe 2016 method is used and a single score is calculated including eighteen (midpoint) impact categories (see Figure 4). Similar to the GWP results, the main drivers for overall environmental impact are electricity use during production, followed by the production of medium ingredients. Similarly switching to sustainable energy results in significant drop in single score results (conventional energy $354 \mathrm{mPt} / \mathrm{kg}$ cultured meat to sustainable energy $130 \mathrm{mPt} / \mathrm{kg}$ cultured meat). 
Looking at the contribution of the different impact categories to the single score impacts, climate change and fine particulate matter formation are the main contributors (total $80 \%$ ). Particulate matter impacts are primarily driven by the production of medium ingredients and by mining and raw material processing for electricity production.

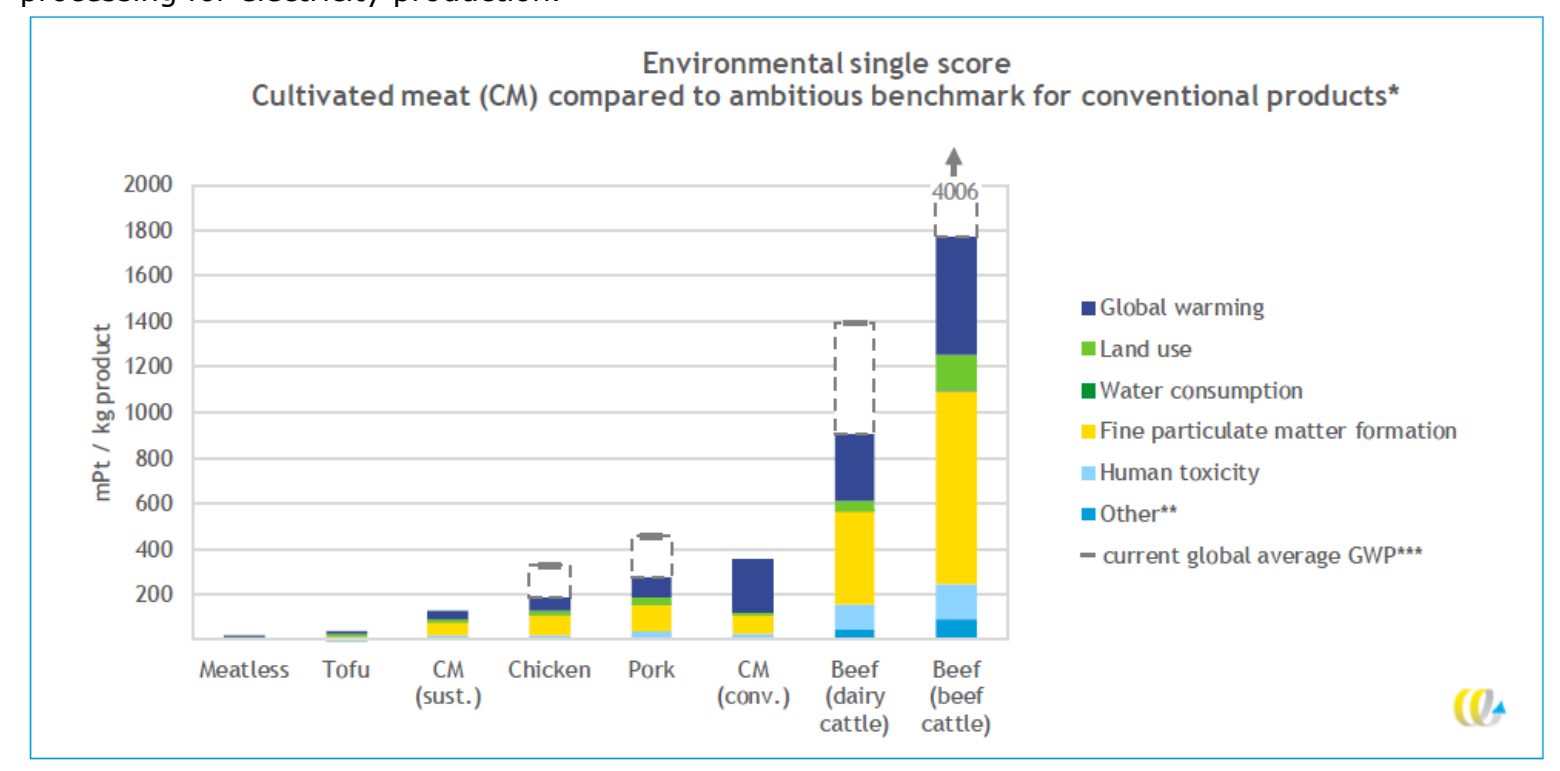

** Other impact categories are 14 other midpoint impact categories of ReCiPe method

*** Current global average GWP taken from (Poore and Nemecek, 2018)

Figure 4 Comparison of environmental single score results (ref: CE Delft study (P Sinke and Odegard, 2021))

\subsection{Comparison with meat and other meat alternatives}

The carbon footprint of conventional meat products varies significantly on a global level. Accordingly, the data used for comparison with conventionally produced animal meat products differ between the reviewed studies. To provide a comparative overview in this section, benchmark data provided in the CE Delft study is taken as reference as more recent data are used in this study. However, as described in section 3.3.4, an ambitious benchmark is considered in the CE Delft study (intensive, WestEuropean, circular agriculture, LUC-free soy). This can be considered representative of the lower end of environmental impact of conventional products in 2030. But for GWP results, also a range is provided in the study showing at the high end current global average meat production impacts based on Poore and Nemecek (2018) (Poore and Nemecek, 2018). Furthermore, Meatless (a plant based texturized meat replacement product) and tofu are also included in the comparison. The comparative results for the impact categories GWP, land use, water use and particulate matter are provided in Table 6. The environmental impacts are also presented graphically in Figure 5 relative to cultured meat, conventional energy scenario. 


\begin{tabular}{|l|l|l|l|l|l|l|l|}
\hline Impact category & $\begin{array}{l}\text { Cultured } \\
\text { meat }\end{array}$ & $\begin{array}{l}\text { Beef } \\
\text { (beef } \\
\text { cattle) }\end{array}$ & $\begin{array}{l}\text { Beef } \\
\text { (dairy } \\
\text { cattle) }\end{array}$ & Pork & Chicken & Tofu & Meatless \\
\hline $\begin{array}{l}\text { GWP, } \mathrm{kg} \mathrm{CO} \text { eq/kg } \\
\text { product }\end{array}$ & $2.5-13.6$ & $30-99$ & $17-32$ & $5-14$ & $3-11$ & 1 & 0.4 \\
\hline $\begin{array}{l}\text { Land use, m²a/kg } \\
\text { product }\end{array}$ & $1.7-1.8$ & 31.6 & 8.8 & 6.0 & 4.6 & 1.8 & 0.2 \\
\hline $\begin{array}{l}\text { Water use, m²/kg } \\
\text { product }\end{array}$ & $42-56$ & 258 & 115 & 40 & 46 & 27 & 2 \\
\hline $\begin{array}{l}\text { Particulate matter, } \\
\text { gPM2.5eq/kg product }\end{array}$ & $5.8-8.1$ & 80.5 & 38.6 & 11.3 & 8.1 & 1.2 & 0.6 \\
\hline
\end{tabular}

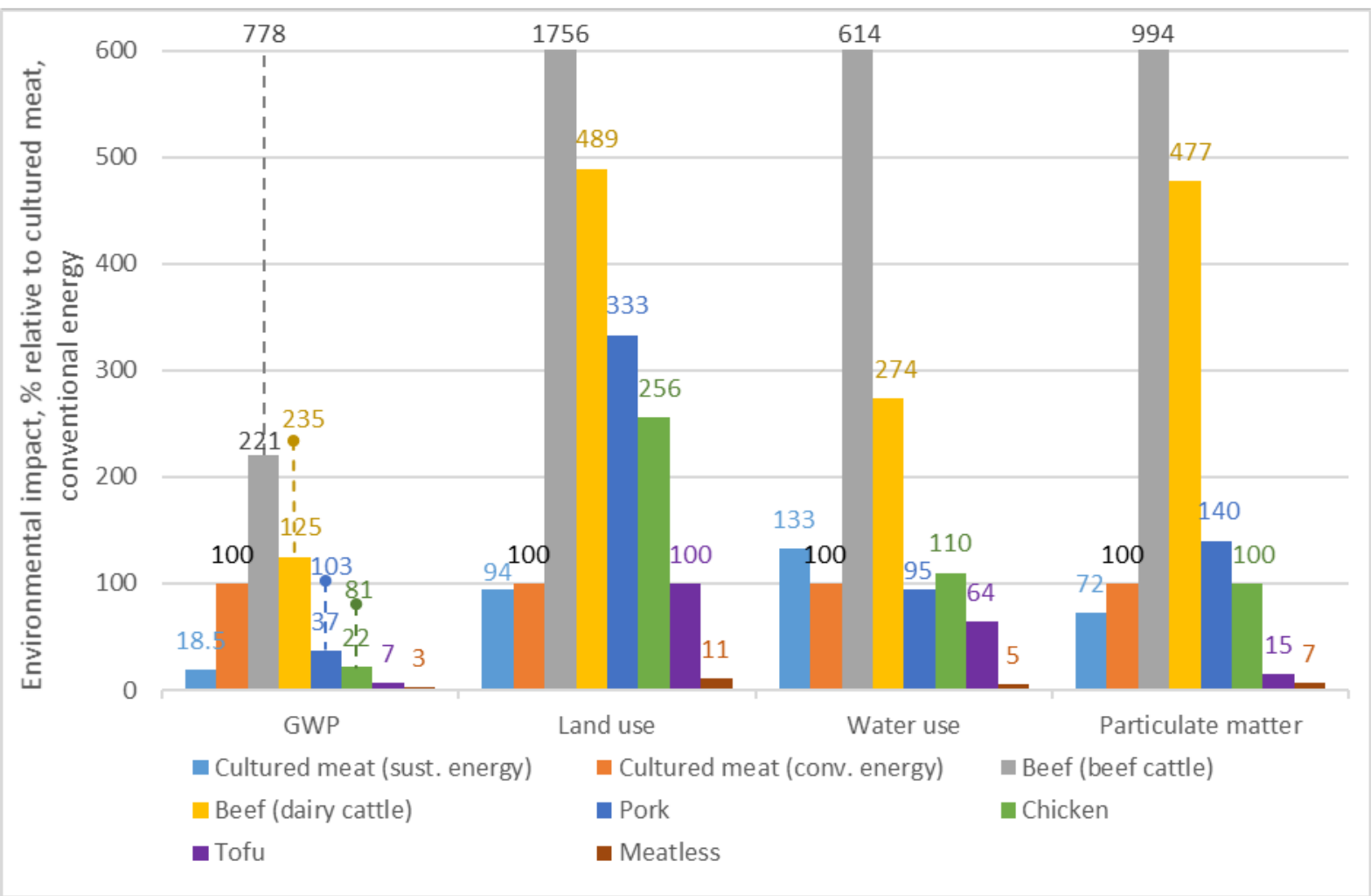

Figure 5

Comparison of environmental impact of cultured meat with conventional
meat and other meat alternatives (based on data obtained from CE Delft
study (P Sinke and Odegard, 2021), for GWP dotted lines indicate current
global average meat production impacts from (Poore and Nemecek, 2018))

For all impact categories, cultured meat performs favourable to beef from both beef cattle and from dairy cattle. (The impact of beef from dairy cows are lower due to environmental impact allocated to milk production.) Also, for all impact categories cultured meat performs worse than plant-based alternatives considered. This is mainly due to the energy-intensive production of cultured meat. Only for land use similar impact with tofu is observed.

Differences between the environmental impacts of cultured meat and pork \& chicken are lower and thus depend on model parameters. For GWP, the comparison is very much dependent on the energy mix considered for cultured meat. While pork and chicken have lower carbon footprints than cultured meat in the conventional energy scenario, for sustainable energy scenario lower footprint is calculated for cultured meat. It is considered comparable when at least $30 \%$ of energy is sourced sustainably (P Sinke and Odegard, 2021). Particulate matter is an important contributor to overall environmental impacts for conventional meat products and about $90 \%$ of this is due to ammonia emissions. Whereas for cultured meat production emissions are mainly due to production of energy used in the meat cultivation and overall perform better than pork and comparable to chicken. 
For land use, cultured meat performs much better than conventional meat products. For water use, cultured meat performs comparable to chicken and pork. For sustainable energy scenario a higher water footprint is calculated which is traced back to the production of solar cells (P Sinke and Odegard, 2021).

\subsection{Interpretation: hotspots and sensitivity analysis}

The last phase of LCA is interpretation which concerns evaluating the results and drawing recommendations and conclusions from the analysis. Evaluation of results involves identifying the processes that contribute significantly to each impact category (hotspots) as well as a sensitivity analysis on key input parameters to test the robustness of the results.

\section{Hotspots}

After the literature review the main identified hotspots are: electricity demand and medium production. The electricity demand for cell growth was found to have the highest contribution to environmental impacts. In all reviewed studies, it accounted for about $70 \%$ of total energy use and GHG emissions. Tuomisto et al. describes that the major energy input in the cultivation of cultured meat consists of cooling required to maintain the bioreactor temperature at $37^{\circ} \mathrm{C}$ and heating required to heat the nutrition media (Tuomisto et al., 2014). Looking at electricity use per stage in the CE Delft study, $83 \%$ was for large-scale proliferation where the main driver is the heat exchanger (91\%) cooling the bioreactor where active cooling was considered (P Sinke and Odegard, 2021). Whereas, in Mattick et al. thermal regulation was modelled as the process of pumping water at ambient temperature $\left(23^{\circ} \mathrm{C}\right)$ through a heat exchanger in the bioreactor walls therefore showing lower electricity use for this (Carolyn S. Mattick et al., 2015).

Following electricity demand, medium production (production of the ingredients/feedstocks and the energy use) showed significant contribution to impacts. In Tuomisto and de Mattos, cyanobacteria production accounted for $23 \%$ of total energy use and $28 \%$ of GHG emissions (Tuomisto and de Mattos, 2011). In Tuomisto et al. wheat and corn cultivation contributed to $6-14 \%$ of energy use and $32-49 \%$ of GHG emissions (Tuomisto et al., 2014). Production of the medium including the feedstocks contributed to about $27 \%$ of environmental single score and GHG emissions in conventional energy scenario ( $P$ Sinke and Odegard, 2021). Mattick et al. showed higher contribution for medium production (about $50 \%$ of energy use and GHG emissions) where the majority was due to the production of other ingredients in basal media (amino acids, minerals and vitamins) and agricultural production of feedstocks showed relatively smaller contribution (Carolyn S. Mattick et al., 2015).

\section{Sensitivity analysis}

Since the inventory data is mostly based on lab scale data and on simulations models, the results face high uncertainties due to the assumptions being made. Both Tuomisto and de Mattos (Tuomisto and de Mattos, 2011) and Mattick et al. (Carolyn S. Mattick et al., 2015) carried out Monte Carlo analysis to indicate uncertainty in results. Especially the error bars depicted in Mattick et al. indicate that large deviations in results can be seen where most significant variability were considered for facility size and maximum cell density. Whereas, in Tumosto and de Mattos the considered uncertainty ranges were narrower resulting in shorter error bars.

Table 7 provides an overview of the sensitivity analysis performed in reviewed studies. Overall, the results were seen to be very sensitive to some parameters such as cell density and medium use.

Tuomisto and de Mattos varied the following parameters (Tuomisto and de Mattos, 2011):

a. Cyanobacteria yield ( $40 \%$ increase in $\left.t . h a^{-1} \cdot \mathrm{yr}^{-1}\right)$

b. Fertilizer use (no fertilizer use by switching to nitrogen fixing cyanobacteria species)

c. Transportation distance (100 km increase)

d. Energy inputs (50\% increase in power demand for sterilization, aeration and rotation in bioreactor, and steel production for bioreactor)

e. Allocation (allocation of $100 \%$ of cyanobacteria production to cultured meat)

f. Water use (use of fresh water instead of sea water for cyanobacteria production). 
The results were most sensitive to the changes in energy requirements for muscle cell cultivation (aeration and rotation) and the change to $100 \%$ allocation (10-24\% increase in energy use and GHG emissions) (Tuomisto and de Mattos, 2011). Furthermore, Tuomisto and de Mattos assessed different geographical locations for cyanobacteria production (California, Spain and Thailand). Thailand showed the lowest impacts for energy use and GHG emissions (Tuomisto and de Mattos, 2011).

Tuomisto et al. analysed the impact of use of different feedstocks (cyanobacteria, corn and wheat). Cyanobacteria showed the lowest GHG emissions and land use, wheat the lowest water footprint and corn the lowest primary energy requirement (Tuomisto et al., 2014). Furthermore, they defined and assessed for a best and worst case for cell density which effected the results for primary energy use and GHG emissions (80\% increase) (Tuomisto et al., 2014).

Mattick et al. varied several parameters listed in Table 7. The results were seen to be most sensitive to the variation in facility size, maximum cell density and mass increase during differentiation. If the building size was considered equivalent to a pharmaceutical plant rather than a brewery, the energy use and GHG emissions were estimated to triple. Use of higher cell concentration decreased environmental impacts about $60 \%$ (Carolyn S. Mattick et al., 2015). Furthermore, in the supplementary information, the sensitivity of the results on the allocation method was analysed. Changing the allocation method based on gross chemical energy basis to mass or economic allocation didn't show significant variation in results.

In the CE Delft study several different scenarios were evaluated by variation of model parameters from the baseline scenario. These scenarios are (P Sinke and Odegard, 2021):

- Electricity mix: A conventional energy mix and a sustainable energy mix were considered. In sustainable energy mix, electricity is generated using on-shore wind turbines and solar PV panels (both $50 \%$ ), and heat used is geothermal.

- Production run time: Longer and shorter production run time ( $\pm 25 \%)$ were considered which depends on doubling time (during proliferation stages) and the desired level of maturity of the cells in the final product. This affects the energy and reactor demands.

- Maximum cell density: During proliferation stages, a higher $(x 4)$ and lower $(x 10)$ cell density were considered which depends on e.g. cell type or reactor type. Lower cell density, requires more reactors and affects the energy demands.

- Cell volume: Smaller and larger cell volume were modelled which depends on species type and cell type. Smaller cell volume results in lower cell mass harvested per unit of volume, therefore requires more reactors and higher energy.

- Medium composition and use: Ingredients can be used more or less efficiently, influencing both inputs (amount of nutrients needed) and waste output. Low-medium and high-medium scenarios were considered.

It was seen that switching from conventional to sustainable energy mix influences the results significantly (lowers the environment impact by $60 \%$ for the single score and $80 \%$ for the carbon footprint) and positions the cultured meat as the best environmental performance in comparison with conventional meat products. Moreover, variation in medium use was found to influence the results substantially where less efficient medium use resulted in about $40 \%$ higher impacts. Lower cell density and smaller cell volume also resulted in about $30 \%$ higher impacts (both environmental single score and carbon footprint). The results were less sensitive to variation in production run time, and increase in cell density and cell volume (max 5\% variation) (P Sinke and Odegard, 2021).

Table 7 Sensitivity analysis performed in the reviewed studies

\begin{tabular}{|l|l|}
\hline Reference & Varied parameters \\
\hline $\begin{array}{l}\text { (Tuomisto and de } \\
\text { Mattos, 2011) }\end{array}$ & $\begin{array}{l}\text { Geographical location, cyanobacteria yield, fertilizer use, transportation } \\
\text { distance, energy inputs, allocation and water use }\end{array}$ \\
\hline (Tuomisto et al., 2014) & Feedstock used and Cell density \\
\hline $\begin{array}{l}\text { (Carolyn S. Mattick et } \\
\text { al., 2015) }\end{array}$ & $\begin{array}{l}\text { Facility size, maximum cell density, facility energy use, cell growth rate, mass } \\
\text { increase during differentiation, corn and soybean yields and allocation method }\end{array}$ \\
\hline $\begin{array}{l}\text { (P Sinke and Odegard, } \\
\text { 2021) }\end{array}$ & Energy mix, production run time, cell density, cell volume and medium use \\
\hline
\end{tabular}




\subsection{Discussion on methodological choices and recommendations}

The ISO 14040/14044 standards for LCA do not give fixed rules for methodological choices. This gives freedom of choice to users to select what they consider the most appropriate. The results often depend strongly on these choices.

\subsubsection{System boundaries}

The focus at this stage is on the process of cultured meat production and the consideration of a cradle to gate assessment by all the reviewed studies is suitable. However, this does not provide the full comparison of the impacts of cultured meat with respect to conventional meat products during the whole life cycle. It can be considered that the environmental performance of cultured meat can be more favourable if the whole life cycle was compared. The transportation and refrigeration impacts for cultured meat are likely to be lower because the production sites may be located closer to the consumers and cultured meat has a lower mass because the excess bones and fat of conventional meat are not present. Therefore, it is recommended to estimate the total environmental impacts of cultured meat production and compare with the conventional meat production considering the whole life cycle or until consumer use. Smetana analysed the environmental impacts from cradle to consumer table where also distribution and use stages are included (Smetana et al., 2015). This includes transportation to supermarket, cooling in the supermarket, transportation to the consumer and cooling and frying by consumer. However, the study did not provide differentiation between the studied products for these downstream requirements.

While Tuomista et al. include the contribution of infrastructure (manufacture of capital equipment) to the environmental impact, Mattick et al. do not. It is considered that inclusion of infrastructure can be less relevant for industrial high scale processes and this omission can be justified especially considering the high uncertainty of ex-ante assessments. In consideration of what processes should be part of the product system, it is important to consider and be consistent with the goal and scope definition of the study. For example, if the goal is to compare different bioreactor configurations, then it will add value to the comparison if the infrastructure is also included in the assessment. Also, in order to provide a fair comparison, it is important to consider whether infrastructure is included or not in the computation of the reference values used for the conventional meat product systems.

\subsubsection{Functional unit}

All of the reviewed studies used weight-based functional unit and carried out comparison with other products on the same $(1 \mathrm{~kg})$ basis. This choice was related to the consumption of the same amount of product by the consumer. However, as seen in Table 2, the protein and dry matter content among the cultured meat studies differ considerably. Mattick et al. has a considerable lower protein (7\%) and dry matter $(17 \%)$ content compared to other studies with protein content in the range of $18-25 \%$ and dry matter content of $20-30 \%$.

There is also difference between the composition of cultured meat product with conventional meat products (beef, pork and chicken) and plant based meat alternatives (such as tofu, Meatless). Plant based meat alternatives typically have lower protein content. Therefore, for comparison the nutritional value need to be considered in the functional unit. Animal food products, from a nutritional point of view, are mainly consumed for their protein. As the products contain different percentages of protein, for example, Tuomisto et al. included an additional comparison per kg protein basis including animal (beef, sheep, pork, poultry, fish, eggs and milk) and plant based protein sources (pulses, vegetal meat substitutes) based on data from Nijdam et al. (Nijdam et al., 2012; Tuomisto et al., 2014). On a kg protein basis, the GWP of beef and sheep were reported the highest. The GWP of pork, poultry, fish, eggs and cultured meat were reported to be similar and the lowest GWP impact was seen for pulses (Tuomisto et al., 2014).

However, it is important to remember that the quality of the protein contained should be considered. Protein Digestibility Corrected Amino Acid Score (PDCAAS) has been adopted as the preferred method 
for measurement of the protein value in human nutrition (Schaafsma, 2000). Smetana et al. considered this additional correction for the digestibility of the protein and corrected the protein content with PDCAAS score for comparison. They calculated that to get to $0.3 \mathrm{~kg}$ of digestible protein content (alternative FU) would require $0.97 \mathrm{~kg}$ of chicken meat, $2.4 \mathrm{~kg}$ of dairy-based, $1.25 \mathrm{~kg}$ of labgrown, $2.6 \mathrm{~kg}$ of insect-based, $3.33 \mathrm{~kg}$ of wheat protein-based and $1.82 \mathrm{~kg}$ of soy meal-based (Smetana et al., 2015). The study of Sonesson et al. (2017), comparing different functional units based on protein content, shows that protein quality and digestibility is of importance and affects the environmental impact per unit (Sonesson et al., 2017).

Additionally, Smetana et al. considered that the basic function of food for people is to supply energy for functioning of the body. Accordingly, an alternative functional unit was included considering the calorific energy content of the products. They were compared on the same calorific energy value (3.75 MJ). The choice of such approach changed the comparison from $1 \mathrm{~kg}$ of each product to: $0.3 \mathrm{~kg}$ for chicken and cultured meat, $0.4 \mathrm{~kg}$ for dairy-based, $0.9 \mathrm{~kg}$ for insect-based, $0.375 \mathrm{~kg}$ for glutenbased, $1 \mathrm{~kg}$ for soy meal-based (Smetana et al., 2015). However, the energy calorific content does not reflect the full nutritional and quality aspects and accordingly the functional unit in term of supplying the consumer the same amount of digested proteins is considered to provide a more suitable comparison.

Apart from protein, animal products also supply other important nutrients. Oily fish are important sources of vitamin D and long chain omega 3 fatty acids. Red meat is a large source of iron and vitamin B12. Therefore to be nutritionally equivalent, cultured meat products would need to provide all of the essential amino acids, along with vitamin B12, an essential vitamin found solely in food products of animal origin. For better comparison in terms of functionality the inclusion of these nutrients and vitamins to cultured meat products would be recommended.

\subsubsection{Impact categories and assessment methods}

Apart from the CE Delft study, limited impact assessment categories (GWP, energy use, land use and water use) were considered by the other LCA studies. It is recommended to have a comprehensive coverage of impact categories and use of scientifically acknowledged and well-established impact assessment methods. The CE Delft study used ReCiPe method which is comprehensive and wellestablished. However, for the European context it is recommended to use the European Commission's Product Environmental Footprint (PEF) method (European Commission, 2018).

Chriki and Hocquette also considered the time dimension of GHG emissions. Where, conventional meat production releases mainly methane emissions, cultured meat production releases carbon dioxide from energy use. Methane does not accumulate as long in the atmosphere whereas $\mathrm{CO}_{2}$ persists (Chriki and Hocquette, 2020).

\subsubsection{Allocation method}

The allocation method used varied between the studies. If the main product and side-product have high difference in value, economic allocation would be applicably and most often used in assessing agricultural or food systems. For comparability of the studies it is important to have the same choice of allocation methods between studies as different methods could lead to quite large differences in final results. Accordingly, it would also be recommended to carry out a sensitivity analysis of the results to the choice of allocation method, as was done by Mattick.

\subsection{Sustainability issues beyond LCA}

\subsubsection{Health}

It is advocated that cultured meat products are safer than conventional meat because they are produced in a controlled environment and do not have the risk of contact with intestinal pathogens such as E. coli and Salmonella as in conventional meat. Also, it is considered that the close monitoring 
can prevent risk of an outbreak which requires the use of antibiotics. Yet it is argued that preventing contamination and infection will become challenging as the manufacturing is scaled up from laboratory to factory scale.

Given the great number of cell multiplications taking place some dysregulation, which happens in cancer cells, is likely (Chriki and Hocquette, 2020). However, it is argued in literature that this can be detected and eliminated from consumption (Chriki and Hocquette, 2020). Additionally, cell culture needs growth factors to sustain cell proliferation, it should be ensured that none of them have negative effects on human health in the short and long term (Chriki and Hocquette, 2020).

The nutritional content of cultured meat can be adjusted and certain micronutrients can be included such as omega-3 fatty acids, vitamin B12 and iron. So, in theory cultured meat can provide the same nutritional profile as conventional meat. However, Chriki and Hocquette (2020) point out that this needs to be introduced in an appropriate matrix to potentiate positive effects of micronutrients on human health and this is not yet well understood. And existing studies do not have strategies to introduce these micronutrients specific to animal products that contribute to good health. Parodi et al. highlight that more information on bioavailability, digestibility, allergies, and food safety is crucial to help us better understand the potential role of future foods in human diets (Parodi et al., 2018). Cultured meat may face high legal-institutional challenges, given untested human health effects (van der Weele et al., 2019).

\subsubsection{Animal welfare}

Cultured meat is considered as a means to stop the cruel practices endured by animals that are sometimes confined in tight spaces and slaughtered in inhumane conditions for conventional meat production. To produce cultured meat still some animals have to be reared to harvest cells. It was additionally considered that animal serum (best known fetal bovine serum) to be used in culture media that can support cell growth and proliferation. Yet, this requires use of blood of a dead calf. Therefore, serum-free media are preferred over animal serum and this was also taken up in the reviewed studies. This reduces reliance on livestock-derived components. Accordingly, the number of slaughtered animals for cultured meat can be significantly lower than conventional meat. Schaefer and Savulescu investigated possible concerns about violation of respect, reduction in happy animals, and facilitation of cannibalism and concluded none of them are sufficient to ground serious opposition to the development of cultured meat (Schaefer and Savulescu, 2014).

\subsubsection{Sensory properties}

Conventional meat products offer a diversity of cuts and different breeds and types of animals. It is difficult to achieve the same sensory properties with cultured meat. Considerable development is still needed to create, for example, a steak type of product.

The flavour and texture are also effected with blood, connective tissue and intramuscular fats present in meat which are not present in cultured meat. Recently, a range of plant-based meat replacers become available in the market mimicking the texture and visual of conventional meat products yet their uptake has been slow and consumption of livestock meat is still increasing (Tuomisto, 2019). If cultured meat can deliver on the sensory properties, they can be preferred over plant-based alternatives by people who do not want to change the composition of their diet. However, if they do not, cultured meat may have trouble competing with the plant-based alternatives which are currently much more developed technologically and shown great improvement (Tuomisto, 2019).

\subsubsection{Trade-offs}

Livestock farming systems perform numerous functions. Livestock produce not only meat, but also milk, and eggs, and also wool and leather. They provide income for rural populations and thus support a large part of rural communities. Cultured meat production is likely to happen in urban areas considering the technological and expertise requirements. Furthermore, manure of animals is an important source for nutrient recycling. The impact of biodiversity of cultured meat depend on how the land released from livestock production would be used. For example cattle grazing is considered 
beneficial for biodiversity for maintaining various habitats and species and elimination may not be preferred for biodiversity conservation (Tuomisto, 2019). However, extensive clearing of land occurred in the American rainforests for cattle and soybean production used in animal feed. Deforestation, land conversion, and degradation are major contributors to global warming. Business-as-usual scenarios for animal agricultural expansion suggest significant biodiversity loss due to agricultural expansion (Dudley and Alexander, 2017).

\subsection{Overall conclusions}

This chapter provided an overview on the available studies on LCA of cultured meat. All four are prospective studies, where a future commercial scale production facility is modelled. It is seen that there are major differences in the studies especially considering the processes included and excluded from the system boundary. This results in high variability of environmental impact results for cultured meat among reviewed studies. Detailed comparison of the final results was only possible for GWP because different choice of impact assessment methods hinder comparability along the other impact categories.

The CE Delft study is comprehensive in terms of processes included within the system boundary and has a comprehensive coverage of impact categories. This provides a more accurate representation of environmental performance, and it can be inferred that the impacts in other studies are underestimated. However, the main contributing factors remained consistent across studies and overall the production of scaffolds, production of equipment/reactor and HVAC of the facility showed minor contribution to environmental impacts. Cultured meat production is energy intensive and the use of energy showed the highest contribution in the overall impact. An important option for improvement of environmental performance is seen therefore in the CE Delft study by shifting to sustainable energy. In the CE Delft study, a conservative approach for cooling was chosen (active cooling of the reactors was modelled), whereas the other studies considered using ambient temperature cooling water and this impact is therefore not included. This results in significant variation between the overall results from the previous studies. Following electricity demand, medium production (production of the ingredients/feedstocks and the energy use) showed significant contribution to impacts. Especially due to the amino acid production and recombinant protein production which have a relatively high demand for feedstock, energy, water and chemicals.

Since the inventory data used in the studies is mostly based on lab scale data and on simulations models, the results face high uncertainties due to the assumptions being made. Therefore studies included sensitivity analysis where several different scenarios were evaluated by variation of model parameters. The results were seen to be very sensitive to some parameters such as cell density and medium use. Looking at the comparison of cultured meat with conventional meat products and other meat substitutes, cultured meat was seen to perform significantly better than beef, favourable to pork, similar to chicken, and worse than plant-based alternatives considering current global average production impacts.

Furthermore, a discussion on the methodological choices within the reviewed studies was made. The outcome of this review can be used as recommendations for future LCA studies on cultured meat. One consideration here is extending the system boundary to cover the downstream processing and distribution of cultured meat to the customer where differences can also be observed with conventional meat products that need to be also taken into account for more representative comparison of the environmental performance. Another consideration is when comparing performance with other products and using results obtained from other studies it is important to consider how these comparative products were modelled e.g. was production of the equipment/infrastructure included or not in the system boundary. An important discussion point is the choice of functional unit where weight-based functional unit was chosen in all reviewed studies. However, it is considered more appropriate to carry out a comparison considering the nutritional value of the products e.g. on a basis of providing the same amount of digestible protein. And if possible include additional meat nutrients such as iron and vitamin B12 for a more equivalent functionality in terms of nutritional value. It is further recommended that LCAs studies should have a comprehensive coverage of different 
environmental impacts and a harmonised choice of impact assessment methods. In the CE Delft study a comprehensive coverage was achieved using the ReCiPe method, however the European Commission's PEF method is recommended to be applied in future studies. For a reliable comparison of results of different sources the same methodological choices is needed including the LCIA method, allocation method, how processes are modelled and databases used for background data. Additionally, sensitivity analysis is especially important for processes in development to address the uncertainty in process parameters and assumptions made.

The chapter was concluded by looking at sustainability issues typically not covered in LCA including human health, animal welfare and sensory properties. Finally, typical trade-offs beyond the scope of LCAs were discussed from the transition from conventional meat products to cultured meat products. 


\section{Conclusions \& recommendations}

Protein alternatives are crucial for a sustainable food production in future. For this purpose different initiatives have been taken, including plant based alternatives and cultured meat. Cultured meat is presented as a good alternative for consumers who want to be more sustainable but do not wish to change their diet. To validate this sustainability claim, we evaluated four LCA studies on cultured meat. When comparing overall environmental impact of cultured meat with conventional meat products and other meat substitutes, cultured meat was seen to perform significantly better than beef, favourable to pork, similar to chicken, and worse than plant-based alternatives considering current global average production impacts.

In this study, we also looked at the boundaries and limitations of current LCA's. It is important to realize that currently no commercial scale cultured meat facility is operational. Therefore, all LCA studies can only model a future facility, extrapolating scientific and small scale facilities. The system boundaries are not always the same in different studies, and these choices lead to high variability of environmental impact results for cultured meat among reviewed studies. The CE Delft study is most comprehensive in terms of processes included and coverage of impact categories. This provides more accurate representation of environmental performance, it is likely that the impacts in other studies are underestimated. The LCA system boundaries mostly include the cultivation related processes, such as feedstock for the medium, fermentation processes, and scaffold production. Product formulation and distribution are not taken into account, probably also because a the lack of data. An important technical bottleneck that is not addressed are the large volumes of the fermenters and the extended cultivation times, which will need extraordinary sterility measures.

One of the strengths of LCA analysis, is that it allows identification of parameters that need to be improved to (further) increase the sustainability of cultured meat production in the future and provide valuable input for defining policies for stimulating the development and market introduction of this new technology. Cultured meat production is energy intensive and use of energy showed the highest contribution in the overall impact. Especially cooling of the reactors is an important consumer of (electrical) energy. Next, medium production showed significant contribution to impacts. Especially the amino acid production and recombinant protein production for growth factors have a relatively high demand for feedstock, energy, water and chemicals. Sensitivity analysis of model parameters showed that parameter choices on cell density and medium use impacted the results most.

For future LCA studies, it is recommended to extend the system boundary to cover the downstream processing and distribution of cultured meat to the customer where environmental performance differences can also be observed with conventional meat products. When comparing LCA studies it is important to consider how these comparative products were modelled.

An important discussion point is the choice of functional unit where weight-based functional unit was chosen in all reviewed studies. However, it is considered more appropriate to carry out a comparison considering the nutritional value of the products e.g. on a basis of providing the same amount of digestible protein. Also other meat nutrients such as iron and vitamin B12 can be taken into account.

Technically, the cultured meat industry is still very much in development. Plant-based alternatives are already well advanced owing to 16 billion USD invested in start-ups and companies offering vegetable meat substitutes. Investments in start-ups working on cultured meat are only about

100 to 200 million USD since 2015 (Chriki and Hocquette, 2020). Obvious improvements that are needed are the reduction in energy, development of scaffolds, and lower medium cost, specifically in developing cheaper plant based growth factors that are non GMO. Also product development is at its infancy. Only a layer of cells can be produced, and these are now presented as minced meat or glued together as nuggets. Essential elements such as fat, structure, colour, flavour, micronutrients and mouthfeel/juiciness need development. 
Cultured meat is part of a movement towards more sustainable meat alternatives that also includes plant based alternatives, insects and microbial protein. This should not be regarded as competition but additional products that target different types of consumers. In combination with other meat alternatives, cultured meat can lead to reduced production and consumption of conventional meat. 


\section{References}

Alexandratos, N., Bruinsma, J., 2012. World Agriculture Towards 2030/2050: The 2012 Revision.

Arora, M., 2013. Cell Culture Media: A Review. Mater. Methods 3, 1-29. https://doi.org/10.13070/mm.en.3.175

Bhat, Z.F., Fayaz, H., 2011. Prospectus of cultured meat--advancing meat alternatives. J. Food Sci. Technol. 48, 125-140. https://doi.org/10.1007/s13197-010-0198-7 LK https://wur.on.worldcat.org/oclc/5245496226

Bomgardner, M.M., 2018. The to-do list for 'clean' meat. Chem. Eng. News 96, 26-31.

Choudhury, D., Tseng, T.W., Swartz, E., 2020. The Business of Cultured Meat. Trends Biotechnol. 38, 573577. https://doi.org/10.1016/j.tibtech.2020.02.012

Choi, K.-H., Yoon, J.W., Kim, M., Lee, H.J., Jeong, J., Ryu, M., Jo, C., Lee, C.-K., 2020. Muscle stem cell isoloation and in vitro culture for meat production: a methodological review. Compr Rev Food Sci Food Saf. 2, 429-457. https://doi.org/10.1111/1541-4337.12661

Chriki, S., Hocquette, J.F., 2020. The Myth of Cultured Meat: A Review. Front. Nutr. 7, 1-9. https://doi.org/10.3389/fnut.2020.00007

Dudley, N., Alexander, S., 2017. Agriculture and biodiversity: a review. Bioediversity 18, 45-49. https://doi.org/10.1080/14888386.2017.1351892

European Commission, 2018. PEFCR Guidance document, Guidance for the development of Product Environmental Footprint Category Rules (PEFCRs), version 6.3.

Finnigan, T., Needham, L., Abbott, C., 2016. Mycoprotein: A Healthy New Protein With a Low Environmental Impact, Sustainable Protein Sources. Elsevier Inc. https://doi.org/10.1016/B978-0-12-8027783.00019-6

Finnigan, T.J.A., 2011. Mycoprotein: origins, production and properties, in: Phillips, G.O., Williams, P.A. (Eds.), Handbook of Food Proteins. Woodhead Publishing Series in Food Science, Technology and Nutrition, pp. 335-352. https://doi.org/10.1533/9780857093639.335

Gaydhane, M.K., Mahanta, U., Sharma, C.S., Khandelwal, M., Ramakrishna, S., 2018. Cultured meat: state of the art and future. Biomanufacturing Rev. 3. https://doi.org/10.1007/s40898-018-0005-1

Gerber, P.J., Steinfeld, H., Henderson, B., Mottet, A., Opio, C, Dijkman, J., Falcucci, A., Tempio, G., 2013. Tackling climate change through livestock: a global assessment of emissions and mitigation opportunities. FAO, https://www.fao.org/3/i3437e/i3437e.pdf.

Handral, H.K., Tay, S.H., Chan, W.W., Choudhury, D., 2020. 3D Printing of cultured meat products. Crit. Rev. Food Sci. Nutr. https://doi.org/10.1080/10408398.2020.1815172

Hanga, M.P., Ali, J., Moutsatsou, P., de la Raga, F.A., Hewitt, C.J., Nienow, A., Wall, I., 2020. Bioprocess development for scalable production of cultivated meat. Biotechnol. Bioeng. 117, 3029-3039. https://doi.org/10.1002/bit.27469

Huijbregts, M.A.J., Steinmann, Z.J.N., Elshout, P.M.F., Stam, G., Verones, F., Vieira, M., Zijp, M., Hollander, A., van Zelm, R., 2017. ReCiPe2016: a harmonised life cycle impact assessment method at midpoint and endpoint level. Int. J. Life Cycle Assess. 22, 138-147. https://doi.org/10.1007/s11367-016-1246$\mathrm{y}$

ISO, 2006a. ISO 14040: Environmental management - Life Cycle Assessment - Principles and framework.

ISO, 2006b. ISO 14044: Environmental management - Life cycle assessment - Requirements and guidelines.

Jiang, G., Ameer, K., Kim, H., Lee, E.J., Ramachandraiah, K., Hong, G.P., 2020. Strategies for sustainable substitution of livestock meat. Foods 9, 1227. https://doi.org/10.3390/foods9091227

Jo, B., Nie M.,Takeuchi, S., 2021. Manufacturing of animal products by the assembly of microfabricated tissues. Essays in Biochemistry. 65, 611-623. https://doi.org/10.1042/EBC20200092

Kounina, A., Margni, M., Bayart, J.B., Boulay, A.M., Berger, M., Bulle, C., Frischknecht, R., Koehler, A., Milà I Canals, L., Motoshita, M., Núñez, M., Peters, G., Pfister, S., Ridoutt, B., Van Zelm, R., Verones, F., Humbert, S., 2013. Review of methods addressing freshwater use in life cycle inventory and impact assessment. Int. J. Life Cycle Assess. 18, 707-721. https://doi.org/10.1007/s11367-012-0519-3

Mattick, Carolyn S., Landis, A.E., Allenby, B.R., Genovese, N.J., 2015. Anticipatory Life Cycle Analysis of In Vitro Biomass Cultivation for Cultured Meat Production in the United States. Environ. Sci. Technol. 49, 11941-11949. https://doi.org/10.1021/acs.est.5b01614

Mattick, Carolyn S, Landis, A.E., Allenby, B.R., Genovese\|, N.J., 2015. S1 . Comparison of this study with prior study. Environ. Sci. Technol. 1-44.

Milà I Canals, L., Chenoweth, J., Chapagain, A., Orr, S., Antón, A., Clift, R., 2009. Assessing freshwater use impacts in LCA: Part I - Inventory modelling and characterisation factors for the main impact pathways. Int. J. Life Cycle Assess. 14, 28-42. https://doi.org/10.1007/s11367-008-0030-z 
Nijdam, D., Rood, T., Westhoek, H., 2012. The price of protein: Review of land use and carbon footprints from life cycle assessments of animal food products and their substitutes. Food Policy 37, 760-770. https://doi.org/10.1016/j.foodpol.2012.08.002

O'Neill, E.N., Cosenza, Z.A., Baar, K., Block, D.E., 2021. Considerations for the development of cost-effective cell culture media for cultivated meat production. Compr. Rev. Food Sci. Food Saf. 20, 686-709. https://doi.org/10.1111/1541-4337.12678

Oonincx, D.G.A.B., de Boer, I.J.M., 2012. Environmental Impact of the Production of Mealworms as a Protein Source for Humans - A Life Cycle Assessment. PLoS One 7, e51145.

Parodi, A., Leip, A., De Boer, I.J.M., Slegers, P.M., Ziegler, F., Temme, E.H.M., Herrero, M., Tuomisto, H., Valin, H., Van Middelaar, C.E., Van Loon, J.J.A., Van Zanten, H.H.E., 2018. The potential of future foods for sustainable and healthy diets. Nat. Sustain. 2018112 1, 782-789. https://doi.org/10.1038/s41893-018-0189-7

Poore, J., Nemecek, T., 2018. Reducing food's environmental impacts through producers and consumers. Science (80-. ). 360, 987-992. https://doi.org/10.1126/science.aaq0216

Post, M.J., 2012. Cultured meat from stem cells: Challenges and prospects. Meat Sci. 92, 297-301. https://doi.org/10.1016/j.meatsci.2012.04.008

Potter, G., Smith, A.S.T., Vo, N.T.K., Muster, J., Weston, W., Bertero, A., Maves, L., Mack, D.L., Rostain, A., 2020. A More Open Approach Is Needed to Develop Cell-Based Fish Technology: It Starts with Zebrafish. One Earth 3, 54-64. https://doi.org/10.1016/j.oneear.2020.06.005

Rubio, N., Datar, I., Stachura, D., Kaplan, D., Krueger, K., 2019. Cell-Based Fish: A Novel Approach to Seafood Production and an Opportunity for Cellular Agriculture. Front. Sustain. Food Syst. 3, 43. https://doi.org/10.3389/fsufs.2019.00043

Rubio, N.R., Xiang, N., Kaplan, D.L., 2020. Plant-based and cell-based approaches to meat production. Nat. Commun. 11, 1-11. https://doi.org/10.1038/s41467-020-20061-y

Santo, R.E., Kim, B.F., Goldman, S.E., Dutkiewicz, J., Biehl, E.M.B., Bloem, M.W., Neff, R.A., Nachman, K.E., 2020. Considering Plant-Based Meat Substitutes and Cell-Based Meats: A Public Health and Food Systems Perspective. Front. Sustain. Food Syst. https://doi.org/10.3389/fsufs.2020.00134

Schaafsma, G., 2000. The protein digestibility-corrected amino acid score. J. Nutr. 130. https://doi.org/10.1093/JN/130.7.1865S

Schaefer, G.O., Savulescu, J., 2014. The Ethics of Producing In Vitro Meat. J. Appl. Philos. 31, 188-202. https://doi.org/10.1111/JAPP.12056

Scharf, A., Breitmayer, E., Carus, M., 2019. Review and gap-analysis of LCA-studies of cultured meat. Nov. Institude Ecol. Innov.

Shahin-Shamsabadi, A., Selvaganapathy, P.R., 2021. Engineering Murine Adipocytes and Skeletal Muscle Cells in Meat-like Constructs Using Self-Assembled Layer-by-Layer Biofabrication: A Platform for Development of Cultivated Meat. Cells Tissues Organs 1-9. https://doi.org/10.1159/000511764

Sinke, P, Odegard, I., 2021. LCA of cultivated meat. CE Delft. Delft, the Netherlands.

Sinke, Pelle, Odegard, I., 2021. LCA of cultivated meat Future projections for different scenarios 49.

Smetana, S., Mathys, A., Knoch, A., Heinz, V., 2015. Meat alternatives: life cycle assessment of most known meat substitutes. Int. J. Life Cycle Assess. 20, 1254-1267. https://doi.org/10.1007/s11367-015-09316

Sonesson, U., Davis, J., Flysjö, A., Gustavsson, J., Witthöft, C., 2017. Protein quality as functional unit - A methodological framework for inclusion in life cycle assessment of food. J. Clean. Prod. 140, 470-478. https://doi.org/10.1016/J.JCLEPRO.2016.06.115

Specht, L., 2020. An analysis of culture medium costs and production volumes for cultivated meat. The Good Food Institute. Washington, D.C., USA.

Specht, L., 2018. Meat by the molecule: Making meat with plants and cells. Biochem. (Lond). 40, 18-21. https://doi.org/10.1042/bio04004018

Swartz, E., 2021a. A summary of recommended stakeholder actions. Anticipatory life cycle assessment and techno-economic assessment of commercial cultivated meat production. The Good Food Institute. Washington, D.C., USA.

Swartz, E., 2021b. A summary of key findings and future directions. Anticipatory life cycle assessment and techno-economic assessment of commercial cultivated meat production. The Good Food Institute. Washington, D.C., USA.

Treich, N., 2021. Cultured Meat: Promises and Challenges. Env. Resour Econ 79, 33-61. https://doi.org/10.1007/s10640-021-00551-3

Tuomisto, H., Ellis, M., Haastrup, P., 2014. Environmental impacts of cultured meat: alternative production scenarios, Proceedings of the 9th International Conference on Life Cycle Assessment in the Agri-Food Sector. ACLCA, Vashon, WA, USA.

Tuomisto, H.L., 2019. The eco-friendly burger. EMBO Rep. 20, e47395. https://doi.org/10.15252/embr.201847395

Tuomisto, H.L., de Mattos, M.J., 2011. Environmental impacts of cultured meat production. Environ. Sci. 
Technol. 45, 6117-6123. https://doi.org/10.1021/es200130u

Van der Weele, C., Driessen, C., 2013. Emerging Profiles for Cultured Meat; Ethics through and as Design. Anim. . https://doi.org/10.3390/ani3030647

van der Weele, C., Feindt, P., Jan van der Goot, A., van Mierlo, B., van Boekel, M., 2019. Meat alternatives: an integrative comparison. Trends Food Sci. Technol. https://doi.org/10.1016/j.tifs.2019.04.018

Vergeer, R., Sinke, P., Odegard, I., 2021. TEA of cultivated meat. CE Delft. Delft, the Netherlands.

Whittaker, J.A., Johnson, R.I., Finnigan, T.J.A., Avery, S. V., Dyer, P.S., 2020. The Biotechnology of Quorn Mycoprotein: Past, Present and Future Challenges, in: Nevalainen, H. (Ed.), Grand Challenges in Fungal Biotechnology. Springer, Cham., pp. 59-79. https://doi.org/10.1007/978-3-030-29541-7_3

Wiebe, M., 2002. Myco-protein from fusarium venenatum: A well-established product for human consumption. Appl. Microbiol. Biotechnol. 58, 421-427. https://doi.org/10.1007/s00253-002-0931-x

Williams, A., Audsley, E., Sandars, D., 2006. Determining the environmental burdens and resource use in the production of agricultural and horticultural commodities. Defra project report IS0205. Bedford, UK. 


\section{Appendix}

\section{Appendix 1 - Cultured meat medium components}

Table 8 Cost of components within Essential 8 medium and their relative cost contribution to a hypothetical 20,000 litre batch, from (Specht, 2020)

\begin{tabular}{|c|c|c|c|c|c|}
\hline Components & $\begin{array}{l}\text { Final } \\
\text { Concentration } \\
(\mathrm{mg} / \mathrm{L})^{\star}\end{array}$ & $\begin{array}{l}\text { Amount per } \\
20,000 \mathrm{~L}(\mathrm{~g})\end{array}$ & Cost per g† & Source Supplier & Cost per $20,000 \mathrm{~L}$ \\
\hline $\begin{array}{l}\text { AA2P (ascorbic } \\
\text { acid 2-phosphate) }\end{array}$ & 64 & 1280 & $\$ 7.84$ & Cayman Chemicals & $\$ 10,035.20$ \\
\hline $\mathrm{NaHCO}_{3}$ & 543 & 10860 & $<\$ 0.01$ & $\begin{array}{l}\text { Alibaba, averaged across } \\
\text { multiple suppliers }\end{array}$ & $\$ 2.39$ \\
\hline $\begin{array}{l}\text { Sodium } \\
\text { selenite }\end{array}$ & 0.014 & 0.28 & $\$ 0.10$ & $\begin{array}{l}\text { Alibaba, averaged across } \\
\text { multiple suppliers }\end{array}$ & $\$ 0.03$ \\
\hline Insulin & 19.4 & 388 & $\$ 340.00$ & Sigma & $\$ 131,920.00$ \\
\hline TGF- $\beta \S$ & 0.002 & 0.04 & $\$ 80,900,000.00$ & R\&D Systems & $\$ 3,236,000.00$ \\
\hline \multicolumn{5}{|c|}{ Total cost per $20,000 \mathrm{~L}$} & $\$ 7,535,958$ \\
\hline \multicolumn{5}{|l|}{ Cost per liter } & $\$ 376.80$ \\
\hline
\end{tabular}



contribution to a hypothetical 20,000 liter batch, from (Specht, 2020)

\begin{tabular}{|c|c|c|c|c|c|}
\hline Components & $\begin{array}{l}\text { Final Concentration } \\
(\mathrm{mg} / \mathrm{L})^{*}\end{array}$ & $\begin{array}{l}\text { Amount per } \\
20,000 \mathrm{~L}(\mathrm{~g})\end{array}$ & Cost per $\mathbf{k g}^{\dagger}$ & $\begin{array}{l}\text { Cost per } \\
\text { Metric Ton }\end{array}$ & $\begin{array}{l}\text { Cost per } \\
20,000 \mathrm{~L}\end{array}$ \\
\hline \multicolumn{6}{|l|}{ Inorganic Salts } \\
\hline Cupric sulfate $\left(\mathrm{CuSO}_{4}-5 \mathrm{H}_{2} \mathrm{O}\right)$ & 0.0013 & 0.026 & $\$ 2.50$ & $\$ 2,500.00$ & $\$ 0.00$ \\
\hline Potassium chloride (KCl) & 311.8 & 6236 & $\$ 0.39$ & $\$ 390.00$ & $\$ 2.43$ \\
\hline Magnesium chloride $\left(\mathrm{MgCl}_{2}\right)$ & 28.64 & 572.8 & $\$ 0.33$ & $\$ 330.00$ & $\$ 0.19$ \\
\hline Magnesium sulfate $\left(\mathrm{MgSO}_{4}\right)$ & 48.84 & 976.8 & $\$ 0.65$ & $\$ 650.00$ & $\$ 0.63$ \\
\hline Sodium phosphate, dibasic $\left(\mathrm{Na}_{2} \mathrm{HPO}_{4}\right)$ & 71.02 & 1420.4 & $\$ 2.10$ & $\$ 2,100.00$ & $\$ 2.98$ \\
\hline Zinc sulfate $\left(\mathrm{ZnSO}_{4}-7 \mathrm{H}_{2} \mathrm{O}\right)$ & 0.432 & 8.64 & $\$ 0.84$ & $\$ 840.00$ & $\$ 0.01$ \\
\hline \multicolumn{6}{|l|}{ Other Compounds } \\
\hline D-Glucose & 3151 & 63020 & $\$ 0.80$ & $\$ 800.00$ & $\$ 50.42$ \\
\hline Hypoxanthine & 2.05 & 41 & $\$ 100.00$ & $\mathrm{n} / \mathrm{a}$ & $\$ 4.10$ \\
\hline Linoleic Acid & 0.042 & 0.84 & $\$ 50.00$ & $\mathrm{n} / \mathrm{a}$ & $\$ 0.04$ \\
\hline Thymidine & 0.365 & 7.3 & $\$ 300.00$ & $n / a$ & $\$ 2.19$ \\
\hline \multicolumn{6}{|l|}{ Amino Acids } \\
\hline L-Alanine & 4.45 & 89 & $\$ 30.00$ & $\mathrm{n} / \mathrm{a}$ & $\$ 2.67$ \\
\hline L-Arginine hydrochloride & 147.5 & 2950 & $\$ 30.00$ & $n / a$ & $\$ 88.50$ \\
\hline $\mathrm{L}$-Asparagine- $\mathrm{H}_{2} \mathrm{O}$ & 7.5 & 150 & $\$ 30.00$ & $n / a$ & $\$ 4.50$ \\
\hline L-Aspartic acid & 6.65 & 133 & $\$ 3.00$ & $\$ 3,000.00$ & $\$ 0.40$ \\
\hline L-Cysteine- $\mathrm{HCl}-\mathrm{H}_{2} \mathrm{O}$ & 17.56 & 351.2 & $\$ 25.00$ & $\mathrm{n} / \mathrm{a}$ & $\$ 8.78$ \\
\hline L-Cystine & 24 & 480 & $\$ 25.00$ & $\mathrm{n} / \mathrm{a}$ & $\$ 12.00$ \\
\hline L-Glutamic acid & 7.35 & 147 & $\$ 30.00$ & $\mathrm{n} / \mathrm{a}$ & $\$ 4.41$ \\
\hline Glycine & 18.75 & 375 & $\$ 2.00$ & $\mathrm{n} / \mathrm{a}$ & $\$ 0.75$ \\
\hline L-Histidine- $\mathrm{HCl}-\mathrm{H}_{2} \mathrm{O}$ & 31.48 & 629.6 & $\$ 50.00$ & $\mathrm{n} / \mathrm{a}$ & $\$ 31.48$ \\
\hline L-Isoleucine & 54.47 & 1089.4 & $\$ 50.00$ & $n / a$ & $\$ 54.47$ \\
\hline
\end{tabular}




\begin{tabular}{|c|c|c|c|c|c|}
\hline Components & $\begin{array}{l}\text { Final Concentration } \\
(\mathrm{mg} / \mathrm{L})^{\star}\end{array}$ & $\begin{array}{l}\text { Amount per } \\
20,000 \mathrm{~L}(\mathrm{~g})\end{array}$ & Cost per $\mathbf{k g}^{\dagger}$ & $\begin{array}{l}\text { Cost per } \\
\text { Metric Ton }\end{array}$ & $\begin{array}{l}\text { Cost per } \\
20,000 \mathrm{~L}\end{array}$ \\
\hline L-Leucine & 59.05 & 1181 & $\$ 15.00$ & $n / a$ & $\$ 17.72$ \\
\hline L-Lysine hydrochloride & 91.25 & 1825 & $\$ 30.00$ & $\mathrm{n} / \mathrm{a}$ & $\$ 54.75$ \\
\hline L-Methionine & 17.24 & 344.8 & $\$ 15.00$ & $\mathrm{n} / \mathrm{a}$ & $\$ 5.17$ \\
\hline L-Phenylalanine & 35.48 & 709.6 & $\$ 28.00$ & $n / a$ & $\$ 19.87$ \\
\hline L-Proline & 17.25 & 345 & $\$ 20.00$ & $\mathrm{n} / \mathrm{a}$ & $\$ 6.90$ \\
\hline L-Serine & 26.25 & 525 & $\$ 40.00$ & $n / a$ & $\$ 21.00$ \\
\hline L-Threonine & 53.45 & 1069 & $\$ 2.50$ & $\$ 2,500.00$ & $\$ 2.67$ \\
\hline L-Tryptophan & 9.02 & 180.4 & $\$ 15.00$ & $\mathrm{n} / \mathrm{a}$ & $\$ 2.71$ \\
\hline L-Tyrosine & 38.7 & 774 & $\$ 35.00$ & $\mathrm{n} / \mathrm{a}$ & $\$ 27.09$ \\
\hline L-Valine & 52.85 & 1057 & $\$ 30.00$ & $n / a$ & $\$ 31.71$ \\
\hline \multicolumn{6}{|l|}{ Vitamins } \\
\hline Biotin & 0.0035 & 0.07 & $\$ 50.00$ & $\mathrm{n} / \mathrm{a}$ & $\$ 0.00$ \\
\hline D-Calcium pantothenate & 2.24 & 44.8 & $\$ 15.00$ & $n / a$ & $\$ 0.67$ \\
\hline Choline chloride & 8.98 & 179.6 & $\$ 35.00$ & $\mathrm{n} / \mathrm{a}$ & $\$ 6.29$ \\
\hline Folic acid & 2.65 & 53 & $\$ 60.00$ & $n / a$ & $\$ 3.18$ \\
\hline i-Inositol & 12.6 & 252 & $\$ 15.00$ & $n / a$ & $\$ 3.78$ \\
\hline Niacinamide & 2.02 & 40.4 & $\$ 7.00$ & $\mathrm{n} / \mathrm{a}$ & $\$ 0.28$ \\
\hline Pyridoxal hydrochloride & 2 & 40 & $\$ 25.00$ & $n / a$ & $\$ 1.00$ \\
\hline Pyridoxine hydrochloride & 0.031 & 0.62 & $\$ 30.00$ & $\mathrm{n} / \mathrm{a}$ & $\$ 0.02$ \\
\hline Riboflavin & 0.219 & 4.38 & $\$ 25.00$ & $n / a$ & $\$ 0.11$ \\
\hline Thiamine hydrochloride & 2.17 & 43.4 & $\$ 40.00$ & $n / a$ & $\$ 1.74$ \\
\hline Vitamin B12 & 0.68 & 13.6 & $\$ 15.00$ & $n / a$ & $\$ 0.20$ \\
\hline
\end{tabular}




\section{Appendix 2 - Key assumptions of LCA-studies}

Table 10 Key assumptions and considered data of LCA-studies, from (Scharf et al., 2019)

\begin{tabular}{|c|c|c|c|}
\hline- & Mattick & Tuomis to $(2011)$ & Tuomis to $(2014)$ \\
\hline $\begin{array}{l}\text { Feedstock origin and } \\
\text { amount }\end{array}$ & $\begin{array}{l}\text { Glucose, glutamine, soy } \\
\text { hydrolys ate and bas al } \\
\text { media (total: } 1.86 \mathrm{~kg} / \mathrm{kg} \\
\text { meat) }\end{array}$ & $\begin{array}{l}\text { Cyanobacteria } \\
\text { hydrolys ate }(0.72 \mathrm{~kg} / \mathrm{kg} \\
\text { meat })\end{array}$ & $\begin{array}{l}\text { Cyanobacteria } \\
\text { hydrolys ate }(0.72 \mathrm{~kg} / \mathrm{kg} \\
\text { meat }) \text {, wheat, corn }(2 \mathrm{~kg} / \\
\mathrm{kg} \text { meat })\end{array}$ \\
\hline $\begin{array}{l}\text { Cell origin and metabolic } \\
\text { requirements }\end{array}$ & $\begin{array}{l}\text { Chines e hamster ovary } \\
(\mathrm{CHO})\end{array}$ & $\begin{array}{l}\text { Stem cells from animal } \\
\text { embryo }\end{array}$ & $\begin{array}{l}\text { Stem cells from animal } \\
\text { embryo }\end{array}$ \\
\hline $\begin{array}{l}\text { Initial cell density in } \\
\text { bioreactor }\end{array}$ & $2 \times 10_{5}$ cells $/ \mathrm{mL}$ & not stated & $\begin{array}{l}1 \times 10_{6} \text { cells and } 2 \times 10_{4} \\
\text { cells }\end{array}$ \\
\hline Maximum cell density & $\begin{array}{l}4 \times 10_{6} \text { cells } / \mathrm{mL} \text { to } \\
\text { account for growth } \\
\text { inhibition due to } \\
\text { metabolic by-products }\end{array}$ & $1 \times 10_{7}$ cells $/ \mathrm{mL}$ & $\begin{array}{l}1 \times 10_{8} \text { cells } / \mathrm{mL} \text { and } 2 \times 10_{8} \\
\text { cells } / \mathrm{mL}\end{array}$ \\
\hline Mass of one cell & $\begin{array}{l}3.5 \times 10-12 \mathrm{~kg}(17 \% \mathrm{DM}, 7 \% \\
\text { prote in }(42 \% \text { on a DM } \\
\text { basis }))\end{array}$ & $\begin{array}{l}3.33 \times 10_{-12} \mathrm{~kg}(30 \% \mathrm{DM}, \\
19 \% \text { protein })\end{array}$ & - \\
\hline Batch duration & $\begin{array}{l}11 \text { days (Proliferation: } 5 \\
\text { days, differentiation: } 3 \\
\text { days, cleaning: } 3 \text { days ) }\end{array}$ & 60 days (cell cultivation) & 90 days (cell cultivation) \\
\hline Scaffold material & $\begin{array}{l}\text { Corn starch microcarrier } \\
\text { beads }\end{array}$ & Excluded & Excluded \\
\hline Bioreactor design & $\begin{array}{l}6 \times 15.000 \mathrm{~L} \text { s tirred-tank } \\
\text { reactors, filling capacity: } \\
100 \%\end{array}$ & $\begin{array}{l}30 \times 1.000 \mathrm{~L} \text { stirred-tank } \\
\text { reactors, weight } 93 \mathrm{~kg} \text {, } \\
\text { filling capacity } 80 \%, 20 \\
\text { years lifetime }\end{array}$ & $\begin{array}{l}\text { hollow-fibre bioreactor, } \\
\text { membrane from PLA, } \\
5 \mathrm{~mm} \text { thick s tainless steel } \\
\text { and } 25 \mathrm{~mm} \text { thick glass } \\
\text { wool, } 20 \text { years lifetime }\end{array}$ \\
\hline Agitation/mixing & $\begin{array}{l}449 \mathrm{~W}\left(29.9 \mathrm{~W} / \mathrm{m}_{3}\right), 1.5 \\
\mathrm{~m} / \mathrm{s}\end{array}$ & $16 \mathrm{~W} / \mathrm{m}_{3}, 100 \mathrm{rpm}$ & $\begin{array}{l}\text { pumping calculated with } \\
\text { low efficiency of } 0.5,16 \\
W / \mathrm{m}_{3}, 100 \mathrm{rpm}\end{array}$ \\
\hline Aeration/sparging & $\begin{array}{l}\text { Atmospheric air at } 2 \mathrm{~kg} \\
\mathrm{O}_{2} / \mathrm{kWh} \text { plus } 4 \% \mathrm{CO}_{2}\end{array}$ & $0.05 \mathrm{vvm}$ & $0.05 \mathrm{vvm}$ \\
\hline $\begin{array}{l}\text { Sterilization of culture } \\
\text { medium }\end{array}$ & $\begin{array}{l}\text { Microfiltration } \\
\text { membranes }\end{array}$ & Autoclaving & Autoclaving \\
\hline Deionization of water & Included & Excluded & Excluded \\
\hline Culture temperature & $37^{\circ} \mathrm{C}$ & $37^{\circ} \mathrm{C}$ & $37^{\circ} \mathrm{C}$ \\
\hline Energy for heating water & $23^{\circ} \mathrm{C}$ to $37^{\circ} \mathrm{C}$ & $\begin{array}{l}\text { Excluded (could be } \\
\text { considered part of the } \\
\text { sterilization energy) }\end{array}$ & $\begin{array}{l}\text { Excluded (could be } \\
\text { considered part of the } \\
\text { sterilization energy) }\end{array}$ \\
\hline $\begin{array}{l}\text { Energy to maintain cell } \\
\text { culture temperature }\end{array}$ & Included & Excluded & Included \\
\hline
\end{tabular}

Table 11

Data quality assessment classification, from (Pelle Sinke and Odegard, 2021)

\begin{tabular}{|l|l|}
\hline \multicolumn{2}{|l|}{ Data quality assessment classification } \\
\hline 0 & No data available at this moment \\
\hline 1 & Primary data from representative process and scale \\
\hline 2 & Primary data from representative process with extrapolation for scale \\
\hline 3 & Primary data from similar process and scale \\
\hline 4 & Secondary data from literature \\
\hline 5 & Estimate or calculation based on expert judgement \\
\hline
\end{tabular}


Table 12

Main model design parameters values, sources and data quality, from (Pelle Sinke and Odegard, 2021)

\begin{tabular}{|c|c|c|c|c|c|}
\hline Main model parameters & Value & Source & $\begin{array}{l}\text { Data } \\
\text { quality }\end{array}$ & $\begin{array}{c}\text { \# of data } \\
\text { points } \\
\text { used }\end{array}$ & $\begin{array}{l}\text { Independent } \\
\text { cross-check }\end{array}$ \\
\hline $\begin{array}{l}\text { Annual production of } \\
\text { commercial facility in } 2030\end{array}$ & 10 kton & $\begin{array}{l}\mathrm{CM} \text { and supply chain } \\
\text { companies }\end{array}$ & 5 & 12 & No \\
\hline Species and cell type & $\begin{array}{l}\text { Various species, assuming } \\
\text { non-GMO cell lines }\end{array}$ & CM companies & 1 & 7 & Yes \\
\hline Type of production & $\begin{array}{l}\text { Semi-continuous production } \\
\text { with } 3 \text { intermediate harvests }\end{array}$ & $\begin{array}{l}\text { Literature, confirmed by } \\
\text { bioprocessing companies }\end{array}$ & 4 & 1 & Yes \\
\hline $\begin{array}{l}\text { Size of largest proliferation } \\
\text { vessel }\end{array}$ & $10,000 \mathrm{~L}$ & $\begin{array}{l}\mathrm{CM} \text { and supply chain } \\
\text { companies estimate } \\
\text { (median) }\end{array}$ & 5 & 7 & Yes \\
\hline $\begin{array}{l}\text { Size and amount of } \\
\text { bioreactors at facility }\end{array}$ & $\begin{array}{l}107 \times 50 \text { L STR, } \\
130 \times 10,000 \text { L STR; } \\
430 \times 2,000 \text { L PR }\end{array}$ & $\begin{array}{l}\text { Calculated, based on } \\
\text { production line presented } \\
\text { in Specht (2020) and } \\
\text { project-specific } \\
\text { parameters }\end{array}$ & $4 / 5$ & $\cdot$ & Yes \\
\hline Doubling time & 30 hours & $\begin{array}{l}\text { Conservative round-up } \\
\text { from Specht (2020): } 28 \\
\text { days. Range validated by } \\
\text { companies. }\end{array}$ & $4 / 2$ & 1 & Yes \\
\hline $\begin{array}{l}\text { Duration of production from } \\
\text { inoculum to harvest }\end{array}$ & $\begin{array}{l}42 \text { days ( } 30 \text { days for } \sim 25 \\
\text { doublings }+2 \text { days for } \\
\text { additional harvests }+ \\
10 \text { days of differentiation } \\
\text { and maturation) }\end{array}$ & $\begin{array}{l}\text { Specht ( } 2020), \text { cross-check } \\
\text { by bioprocessing } \\
\text { companies }\end{array}$ & 4 & 1 & Yes \\
\hline Maximum cell density & $50^{*} 10^{6}$ cells $/ \mathrm{ml}$ & $\begin{array}{l}\text { CM and supply chain } \\
\text { companies (median) }\end{array}$ & 2 & 7 & Yes \\
\hline Avg. cell volume & $3,500 \mu \mathrm{m}^{3} /$ cell & CM companies (median) & 1 & 4 & Yes \\
\hline Density of meat & $881 \mathrm{~kg} / \mathrm{m}^{3}$ & Specht (2020) & 4 & N.a. & No \\
\hline
\end{tabular}




\begin{tabular}{|c|c|c|c|c|}
\hline $\begin{array}{l}\text { Main model inputs and } \\
\text { their production }\end{array}$ & Source & Data quality & $\begin{array}{c}\text { \# of data points } \\
\text { used }\end{array}$ & $\begin{array}{l}\text { Independent } \\
\text { cross-check }\end{array}$ \\
\hline $\begin{array}{l}\text { Energy use for production } \\
\text { (heating, cooling, mixing, } \\
\text { aeration, pumping) }\end{array}$ & $\begin{array}{l}\text { Calculations by bioprocess } \\
\text { engineers with } \\
\text { extrapolations by CE Delft }\end{array}$ & 5 & 1 & Yes \\
\hline $\begin{array}{l}\text { Energy use for cleaning } \\
\text { (CIP/SIP) }\end{array}$ & $\begin{array}{l}\text { Calculations by bioprocess } \\
\text { engineers with } \\
\text { extrapolations by CE Delft }\end{array}$ & 3 & 1 & No \\
\hline Energy use for HVAC & Calculations by engineers & 4 & 1 & No \\
\hline Energy production & $\begin{array}{l}\text { Ecoinvent LCA database, } \\
\text { modelled after global } \\
\text { stated policies scenario in } \\
\text { World Energy Outlook } 2030 \\
\text { (IEA 2019) }\end{array}$ & 1 & N.a. & N.a. \\
\hline $\begin{array}{l}\text { Purified water use for } \mathrm{CM} \\
\text { production (quantity)) }\end{array}$ & $\begin{array}{l}\mathrm{CM} \text { and bioprocess } \\
\text { engineering companies }\end{array}$ & $\begin{array}{l}2 \text { (for medium- } \\
\text { related water } \\
\text { use) and } \\
3 \text { (for cleaning } \\
\text { related water } \\
\text { use) }\end{array}$ & 2 & Yes \\
\hline Purified water production & Water companies & 1 & 1 & No \\
\hline Medium use & $\begin{array}{l}\mathrm{CM} \text { and supply chain } \\
\text { companies }\end{array}$ & 2 & 6 & Yes \\
\hline Medium recycling rate & $\begin{array}{l}\mathrm{CM} \text { and supply chain } \\
\text { companies }\end{array}$ & $\begin{array}{c}0 \\
\text { (no consensus) }\end{array}$ & 6 & Yes \\
\hline Medium composition & $\begin{array}{l}\mathrm{CM} \text { and supply chain } \\
\text { companies }\end{array}$ & 2 & 7 & Yes \\
\hline $\begin{array}{l}\text { Medium ingredient } \\
\text { production }\end{array}$ & See below & & & \\
\hline Hydrolysate & $\begin{array}{l}\text { (Colantoni et al. 2017) } \\
\text { EDIT: Soy LUC set to } 0 \text { (as } \\
\text { is done for conventional } \\
\text { products) }\end{array}$ & 4 & 1 & No \\
\hline Amino acids & $\begin{array}{l}\text { Data from (Marinussen and } \\
\text { Kool 2010), Mattick (2014), } \\
\text { Mattick et al. (2015). } \\
\text { Amino acids modelled: } \\
\text { - L-Glutamine } \\
\text { - L-Threonine } \\
\text { - L-Lysine } \\
\text { - D,L-Methionine }\end{array}$ & 4 & 1 & No \\
\hline Recombinant proteins & $\begin{array}{l}\text { Amino acid production } \\
\text { data from (Marinussen and } \\
\text { Kool 2010), Mattick (2014), } \\
\text { Mattick et al. (2015) used } \\
\text { as basis. Water and } \\
\text { electricity use adapted for } \\
\text { recombinant protein } \\
\text { fermentation with data } \\
\text { from } 2 \text { producing } \\
\text { companies. }\end{array}$ & 2 & 3 & Yes \\
\hline
\end{tabular}




\begin{tabular}{|c|c|c|c|c|}
\hline $\begin{array}{l}\text { Main model inputs and } \\
\text { their production }\end{array}$ & Source & Data quality & $\begin{array}{c}\text { \# of data points } \\
\text { used }\end{array}$ & $\begin{array}{l}\text { Independent } \\
\text { cross-check }\end{array}$ \\
\hline Other medium ingredients & $\begin{array}{l}\text { Ecoinvent and Agri- } \\
\text { footprint LCA databases }\end{array}$ & 1 & N.a. & N.a. \\
\hline $\begin{array}{l}\text { Transport of medium } \\
\text { ingredients }\end{array}$ & $\begin{array}{l}\text { Based on standard } \\
\text { Ecoinvent values for global } \\
\text { markets }\end{array}$ & 1 & N.a. & N.a. \\
\hline Scaffold use & $\begin{array}{l}\mathrm{CM} \text { and supply chain } \\
\text { companies }\end{array}$ & 5 & $\begin{array}{l}8 \text { companies } \\
\text { (total) of which } \\
3 \text { with future } \\
\text { estimate of } \\
\text { quantity of } \\
\text { scaffold used }\end{array}$ & No \\
\hline Scaffold production & See below & & & \\
\hline Hydrogel & De Marco et al. (2017) & 4 & 1 & No \\
\hline Electrospinning & Supply chain companies & 2 & 2 & Yes \\
\hline Bioreactor use & $\begin{array}{l}\text { Size from } \mathrm{CM} \text { and } \\
\text { supplying companies, } \\
\text { amount calculated }\end{array}$ & See above & See above & Yes \\
\hline Bioreactor production & $\begin{array}{l}\text { Tuomisto et al. (2014) and } \\
\text { industry experts within } \\
\text { CE Delft }\end{array}$ & 4 & 2 & Yes \\
\hline $\begin{array}{l}\text { Storage and mixing tanks } \\
\text { use }\end{array}$ & Calculated & 5 & 1 & No \\
\hline $\begin{array}{l}\text { Storage and mixing tanks } \\
\text { production }\end{array}$ & $\begin{array}{l}\text { Industry experts within } \\
\text { CE Delft }\end{array}$ & 4 & 1 & No \\
\hline Filters for filtration use & Supplying companies & 2 & 1 & Yes \\
\hline $\begin{array}{l}\text { Filters for filtration } \\
\text { production }\end{array}$ & Supplying companies & 1 & 1 & No \\
\hline
\end{tabular}

Table 14 Energy mix for 2030, stated policy scenario, global average (IEA 2019), from (Pelle Sinke and Odegard, 2021)

\begin{tabular}{|l|r|}
\hline Source & Share \\
\hline Coal & $29 \%$ \\
\hline Gas & $24 \%$ \\
\hline Oil & $3 \%$ \\
\hline Nuclear & $9 \%$ \\
\hline Hydro & $15 \%$ \\
\hline Wind & $9 \%$ \\
\hline Solar & $9 \%$ \\
\hline Other renewable & $3 \%$ \\
\hline
\end{tabular}

Table 15 Modelled energy demand for 1 year of operation (baseline scenario), from (Pelle Sinke and Odegard, 2021)

\begin{tabular}{|l|l|}
\hline Process & $\begin{array}{l}\text { Quantity } \\
\text { (kWh) }\end{array}$ \\
\hline $\begin{array}{l}\text { Electricity for aeration, agitation, pumping and heat exchanger during small-scale proliferation, } \\
\text { large-scale proliferation and differentiation and maturation; centrifugation and pumping washing } \\
\text { water during harvesting and as part of food safety measures; pumping during cleaning; HVAC; } \\
\text { pumping (medium mixing and sterilization }\end{array}$ & $2,17 \mathrm{E}+08$ \\
\hline $\begin{array}{l}\text { Heat for initial heating of medium during small-scale proliferation, large-scale proliferation and } \\
\text { differentiation and maturation and cleaning; HVAC }\end{array}$ & $1,08 \mathrm{E}+07$ \\
\hline
\end{tabular}





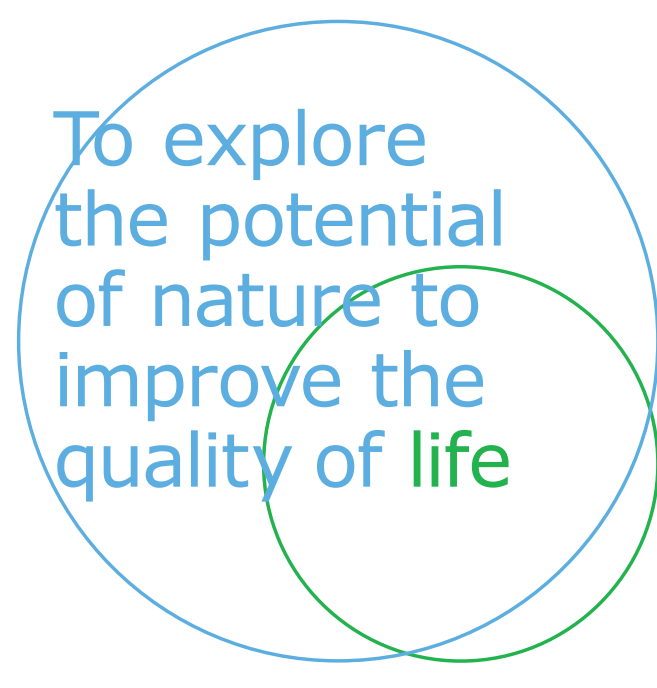

Wageningen Food \& Biobased Research Bornse Weilanden 9

6708 WG Wageningen

www.wur.nl/wfbr

info.wfbr@wur.nl

Report 2248

DOI $10.18174 / 563404$

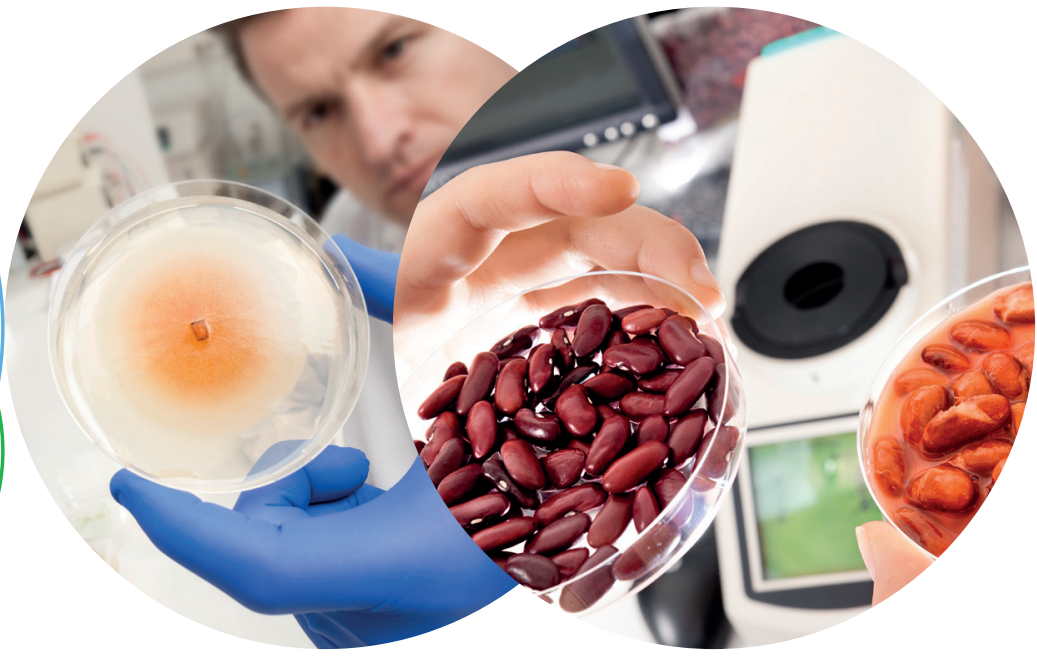

The mission of Wageningen University and Research is "To explore the potential of nature to improve the quality of life". Under the banner Wageningen University \& Research, Wageningen University and the specialised research institutes of the Wageningen Research Foundation have joined forces in contributing to finding solutions to important questions in the domain of healthy food and living environment. With its roughly 30 branches, 5,000 employees and 12,000 students, Wageningen University \& Research is one of the leading organisations in its domain. The unique Wageningen approach lies in its integrated approach to issues and the collaboration between different disciplines. 